\title{
3
}

\section{'The past is always in front of us': Locating Historical Māori Waterscapes at the Centre of Discussions of Current and Future Freshwater Management}

Kia whakatomuri te haere whakamua: I walk backwards into the future with my eyes fixed on the past. -A common Màori proverb

Variations of the common whakatauki 'the past are always in front of you' encompass Māori understandings of time and the importance of knowing one's whakapapa (genealogy) and histories. Such understandings extend to current discussions of the freshwater crisis, climate change and the Anthropocene. Just as rivers cannot be separated into components (river-stream-wetland) and instead must be viewed as ki uta ki tai (from the mountains to the sea), from a mātauranga (Māori knowledge) perspective, the impacts of colonisation cannot be de-coupled from local and global environmental changes (which contribute to past, present, and future social-environmental injustices). A Ngāti Maniapoto waiata catalogued in 1930 references Rukutia twisting flax fibre to create a thread: "Tenei to tohu; Ka mau ki au; Miria mai, e; Te miri o Rukutia", which was translated by Apirana Ngata as "Henceforward your landmarks; Are firmly imprinted within me; Come with your caress; The 
caress of Rukutia” (Ngata 2004, p. 293). The act of weaving also mimics the layering of whakapapa, one generation laid onto another, and highlights the interrelationship between landscapes and peoples. We, thus, begin this story by examining historical waterscapes of the Waipā River catchment and its peoples.

In what follows, we outline the historical and socio-economic landscapes of the tangata whenua of Te Waipā Awa (the Waipā River) before and immediately after the coming of Pākehā (New Zealand European ethnic group). It is, as with all historical works, just one history that can be told, interpreted, and retold in numerous other ways, and which is always partial and subjective. One part of this history resides in Te Ao Māori (the world of Māori), and the other part lies in Te Ao Pākehā (the world of Pākehā aka the settler world) and associated cultural identities (Parsons et al. 2019; Salmond 2017). Although Māori and Pākehā who lived (and continue to live) in the Waipā catchment share commonalities in their respective engagements with their environments, their understandings of and relationships with place are based on different understandings of the environment (ontologies) as well as different modes of living and environmental management practices (epistemologies). The relationships between iwi (tribes) and the Waipā River were/are a complex network of metaphysical and physical connections (see Fig. 3.1). Te Ao Pākehā, on the other hand, situated the Waipā River as a resource or commodity that could be controlled and used to further human prosperity and development activities.

\section{Te Ao Māori (The Māori World)}

The catchment of the Waipā River was home to Māori people for many hundreds of years before when Pākehā first began their visits to Aotearoa (Barrett 2012; Collins et al. 2012; Ellison et al. 2012; Tauriki et al. 2012). Whakapapa ties successive generations of people in the Waipā catchment to Tainui waka (canoe), which was one of the first waka to bring Māori to Aotearoa from their homeland of Hawaiki, in the South Pacific. Early Pacific migrants explored, named and storied, cultivated, settled and defended the lands and waters from Tāmaki Makaurau (modern-day 


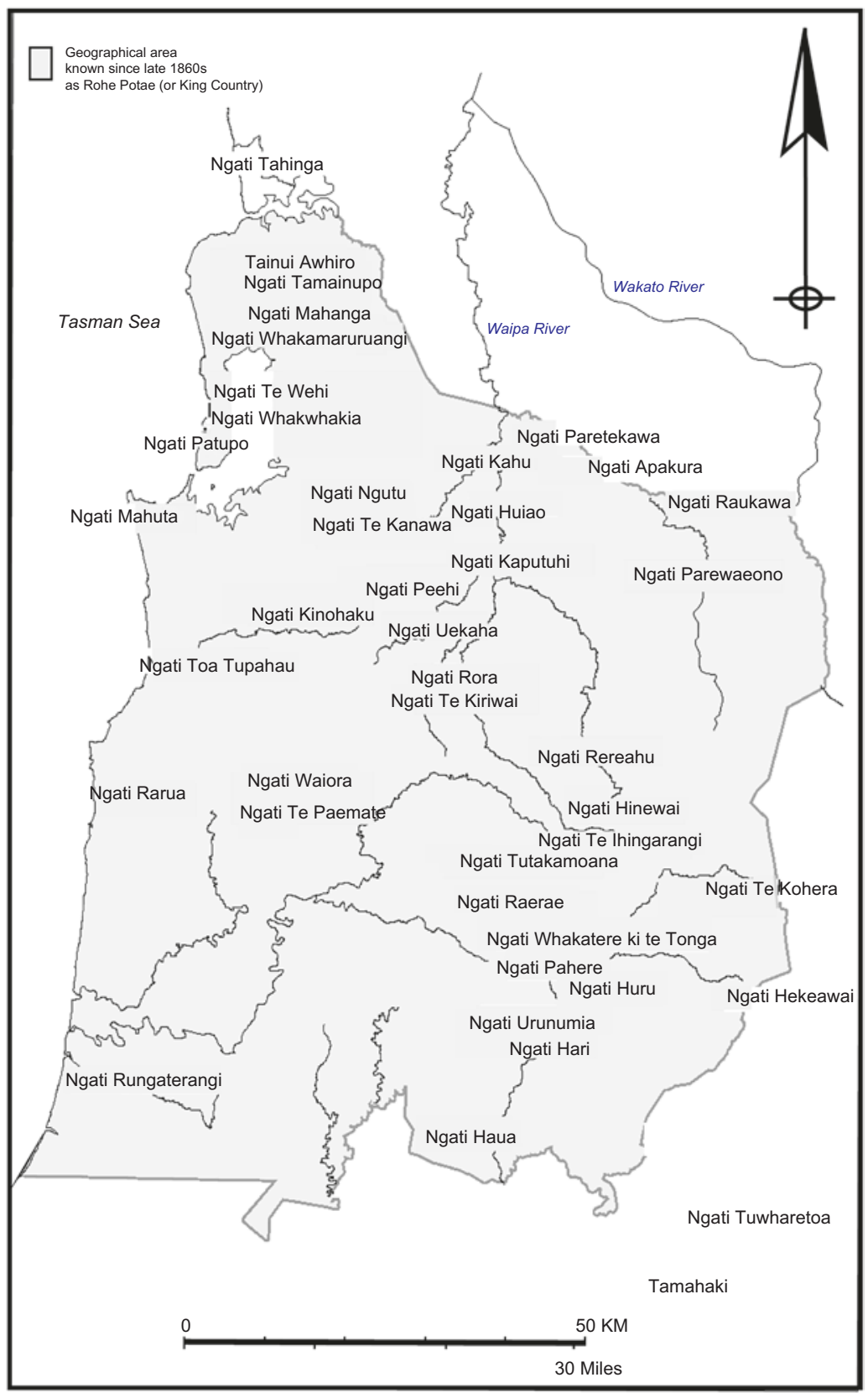

Fig. 3.1 Map showing different iwi and hapū within the Waipā River catchment 
Auckland) in the north to the Poutama and Whanganui in the south. In the east and the south, they met and intermingled with people from other waka (including Tokomaru, Aotea, and Te Arawa) (Tauriki et al. 2012; Te Hurinui Jones 1995). Tribal oral traditions tell of ariki (paramount chief) and rangatira (chief or high rank) who represented and maintained the mana (power, authority and prestige) of their people (within their iwi and hapū_sub-tribes), and whose lives were recorded to include remarkable journeys, significant battles, marriages and familial bonds.

After the Tainui waka made landfall at Tāmaki Makaurau, its leaders made expeditions around the new lands and waters; some by land, others by sea. Many leaders (including Rōtū, Hiaroa, and Rakataura) journeyed south on foot and traversed the Waikato River valley and along the Waikato coastline (Ellison et al. 2012; Tauriki et al. 2012; Te Hurinui Jones 1995). Hoturoa brought the Tainui waka to Kāwhia Harbour, which was its final resting place. He and his wife (Whakaotirangi) established their home at Kāwhia where Whakaotirangi planted the first kūmara (sweet potato Ipomoea batatas), which she had brought with her from Hawaiki. Rakataura and Kahurere travelled through the interior lands, journeying up the mountain Pirongia and southwards along the Waipa River and the ranges to the east of the river. They encountered an environment far colder than their tropical island home in the South Pacific, and many of the crops (such as breadfruit and yams) they brought with them could not grow. However, what the new land provided in abundance was far more space than in Hawaiki. Between Wharepūhunga and Pirongia, Rakataura and Kahurere discovered flat area-the wetlands and floodplains of the Waipā River-and further south the dense forest of Te Nehenehenui, which at the time of their arrival was filled with moa (Dinornithiformes) as well as other smaller species of birds, bats, and edible flora. The floodplains and forests were linked by a mosaic of streams, rivers, and lakes in which a plethora of different types of fish, shellfish, and waterfowl lived. These watercourses also became the region's transport network, for Māori. The Tainui leader Rōtū settled with others besides the Waipā River at Whatawhata (Collins et al. 2012, pp. 49, 55; Tauriki et al. 2012, pp. 94-97, 110-112; Thorne 2011, pp. 47-49). The Tainui peoples were not alone in their new lands; they lived alongside others-including fairy people (patupaiarehe) and fair-haired people 
(urukehu) — who lived on the slopes of the mountains of Pirongia and Kakepuku, and in the forests of Tühua and Pureora (Barber 1978; Cowan 1901; Ellison et al. 2012).

Descendants of Tainui waka initially lived in small family groupings and moved from location to location to allow them to access resources at different times of year (Anderson et al. 2012; Anderson 2002). For example, for hunting or fishing activities, harvesting berries, as well as the cultivation of kūmara and taro (root crops) (Bassett et al. 2004; Furey n.d.; Horrocks et al. 2008; Leach 2005). Initially, Māori hunted moa and other abundant fauna; however, unsustainable harvesting practices, rising human populations, loss of flora, and the introduction of rats resulted in rapid decline in moa numbers (Anderson 2003; Gumbley et al. 2004; Hogg et al. 2017; Worthy and Swabey 2002). Accordingly, the focus of the Māori economy adapted and diversified, and included the year-round harvesting of flora (berries, fern roots) and fauna (fish, eels, shellfish, birds), as well as the cultivation of crops. Horticultural techniques used in Hawaiki were adapted to suit the colder and wetter conditions of the Waikato and Te Rohe Pōtae (The King Country), where it was far more challenging to grow kūmara and taro than in warmer tropical climates. Over centuries, the social structure changed as individual families began to work collaboratively, probably as a way to share the division of labour (collecting foodstuffs, defending territories). Thus, hapū were formed.

Early Māori settlement in the Waipā catchment following the landing of the waka Tainui established the tūpuna (ancestors) of the various hapū and iwi within today's landscape. Important events led to the appearance of one significant tūpuna: Maniapoto, after whom the iwi Ngāti Maniapoto is named. The development of Ngāti Maniapoto as a separate iwi coincided with other groups (who traced their lineage to the Tainui waka) branching out to establish their iwi distinct from Tainui. These groups all continued to engage with one another but maintained separate rohe (tribal lands and waters) (Ellison et al. 2012; Tauriki et al. 2012).

The principal socio-cultural and political grouping from the $1500 \mathrm{~s}$ through until the 1840s was the hapū (Anderson et al. 2012; Anderson 2002). Hapū were made up of several different family (whanau) groups who lived nearby each other, were united by common ancestry, and who worked together under leader(s) (rangatira) for the benefit of all hapū 
members. Natural resources were managed communally, which included the production and sustainable harvesting of resources from lands and waters. Likewise, waka, pā whawhai (often shortened to pā, which are fortified settlements used during conflicts), and other things were communal property held by collectives rather than individuals. Nonetheless, rights overlapped between hapū, with people living in neighbouring areas often related and able to assert their ancestral relationships within another hapu territory. The nature of these territorial rights depended on the specific connections, but usually included rights to seasonal visits or to occupy an area; seasonal or permanent rights to use particular resources (foods, water, cultivations); and rights to travel through space safely. Records highlight how the various hapū of Ngāti Maniapoto moved around seasonally to access the diversity of food sources within tribal boundaries (moving north and south, from inland to the coastal areas). Oral histories recount how people came from far and wide for the annual tuna heke (the migration of freshwater eels) as well as seasonal fishing trips. The rivers and streams were crucial transport routes that allowed people to move around the area and transport themselves and their foodstuffs around the region (see Fig. 3.2) (Tauriki et al. 2012).

\section{Knowledge, Values and Guiding Principles}

Pre-colonial Māori in the Waipā catchment, as elsewhere, held their distinct understanding about the origins of the world, how the universe operated, and the nature of all beings (both living and non-living) (Anderson et al. 2012; Collins et al. 2012; Salmond 2017; Tauriki et al. 2012; Waitangi Tribunal 2018). This understanding extended to their own identities, cultural traditions, and histories; their ways of governing, establishing and maintaining laws, assessing whether the behaviour was correct or incorrect, and systems of social organisation; their values, beliefs, and social norms; their approach to determining rights to resources (including land, water and biota); their approaches to managing their interactions with the environment; and their ways to deal with relationships between people (interpersonal as well as inter-whanau, hapū, and iwi). How Māori understood themselves and their position within the world centred on recognising that a host of different interacting human, biophysical, and 


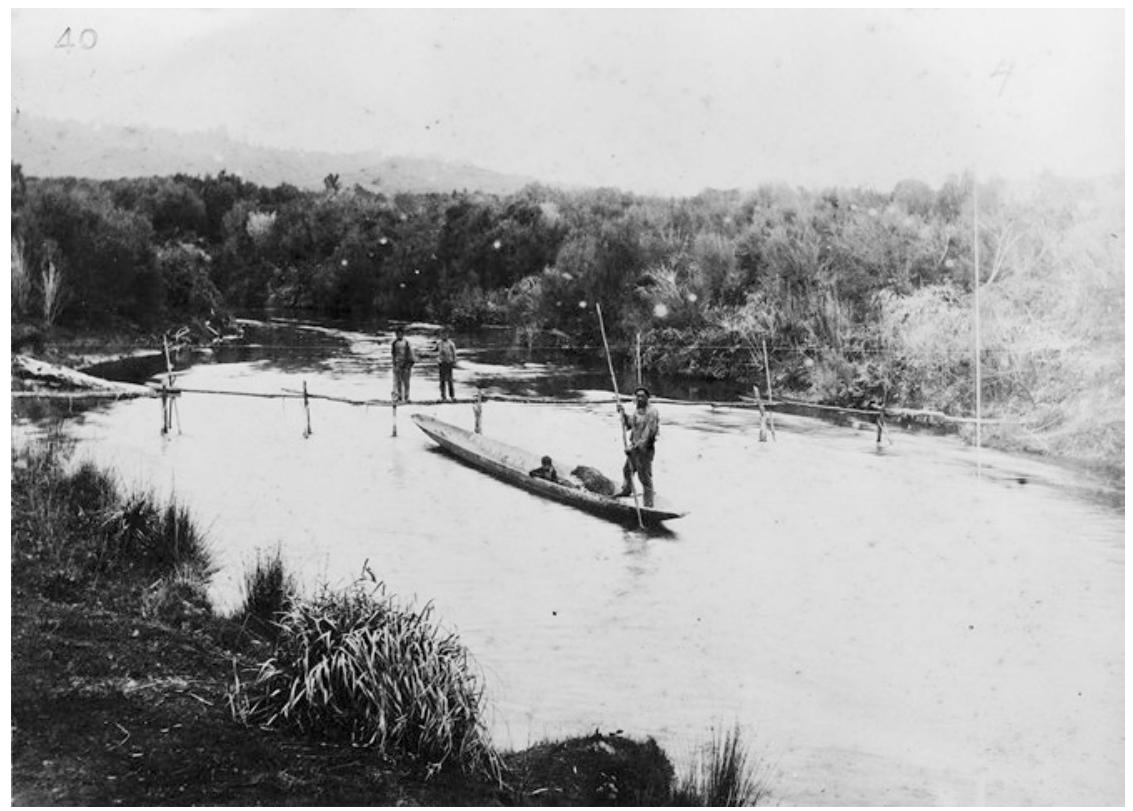

Fig. 3.2 Photograph showing Māori canoe and bridge in a stream (somewhere between Te Kuiti and Te Awamutu) in one of the Waipā River's numerous wetlands circa 1890. The vegetation consists primarily of manuka that was cultivated and harvested by Māori for building materials, to make medicines, and to produce perfumes. (Source: Ref/1/2-045762-F. Alexander Turnbull Library, Wellington, New Zealand)

spiritual forces shaped the world, their environments, and their day-today lives (Mead 2016). At the heart of Māori ways of knowing and thinking (their ontology) is the connectivity of all things (human and more-than-humans). The principle of whanaungatanga (which translates as kinship, relationship, and sense of familial connection) highlights this interconnection and holds that all things (animate and inanimate, living and dead, past and present) were (and are always) linked together (Haar 2009; Harmsworth et al. 2016). All the entitlements, obligations, beliefs, and values and the power to lead and make decisions, originated from the domain of ancestor-gods and fundamentally from Te Korekore (see Fig. 3.3: Whakapapa spiral). All relationships (social and environmental) were interposed through the spiritual realm. 


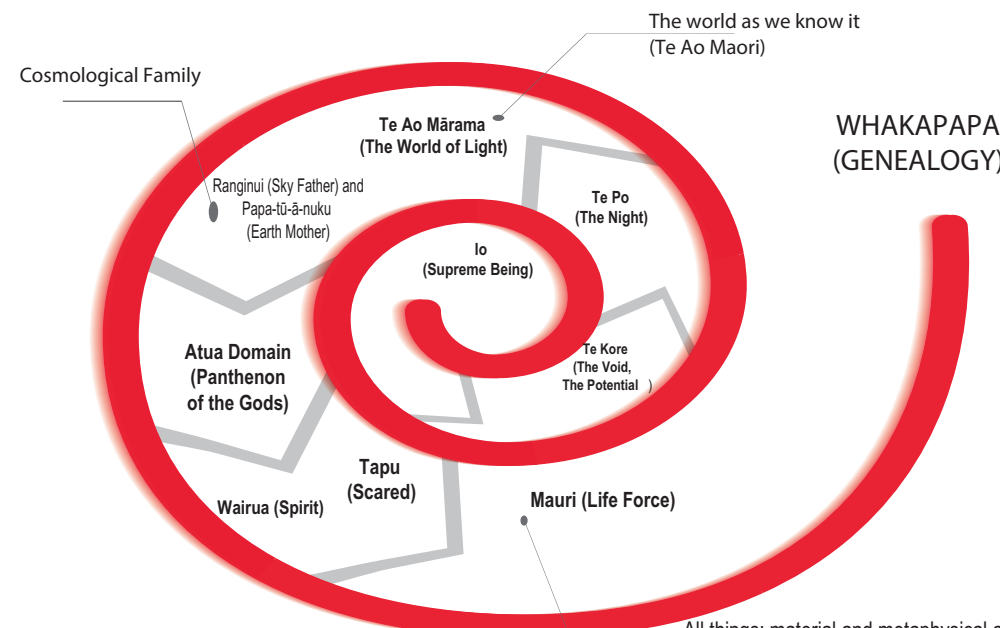

The world as we know it (Te Ao Maori)

All things: material and metaphysical actors (humans, flora and fauna, mountains, rivers and so forth)

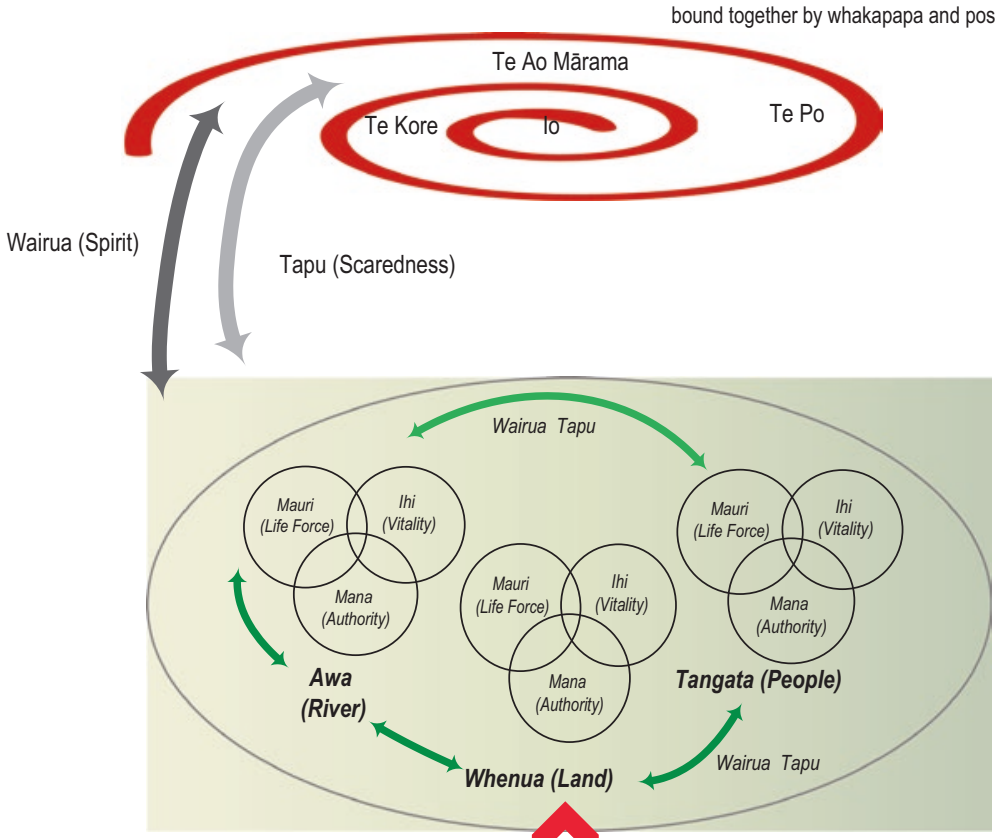

Māturanga Māori (Knowledge),

the application of that knowledge, and Tikanga (customary laws), and practices are all designed to maintain and enhance mana, mauri, and ihi of people, ecosystems, whenua (lands) and awa (rivers) and wai (waters).

Fig. 3.3 Whakapapa spiral 
Tainui oral traditions describe Te Korekore (also shortened to Te Kore), as the Void or original nothingness that existed before everything (including time) (Ellison et al. 2012; Te Hurinui Jones 1995). All of creation (including natural and supernatural beings) came out of Te Kore, which was powered by Io-matua-te-kore (the parentless one or supreme being) the ultimate energy and consciousness believed to be the constant, endless, and original parent of all things and knowledge. ${ }^{1}$ From Io and Te Kore came the two gods Papa-tū-à-nuku (Earth Mother) and Ranginui (Sky Father), who were linked together in such a tight embrace that no light could get through (Salmond 2017). It was into this dark and cramped space that their children lived and some of them eventually conspired to prize their parents apart so that they could live in the light). The children were ultimately successful and became the Atua (gods) of Māori and the progenitors for every part of the world. Tāne-mahuta (God of the Forest) became the atua of all aspects of trees insects, birds, and rocks, and all other aspects of forests. Haumiatiketike became the atua of the plants that could be collected as food for people, while Rongomātāne (the first-born child) became the god of peace as well as cultivated foods. Tangaroa was responsible for governing the oceans as well as all aquatic life, Tāwhirimātea the winds, Rūaumoko the seasons as well as earthquakes and volcanoes. Human beings were the descendants of the god of war (Tūmatauenga). In Tainui oral traditions, however, the spark of life came from Hani (the male essence) and Puna (the female essence) who fashioned Tiki-i-āhua-mai-i-Hawaiki (Tiki-who-was-fashioned-inHawaiki) and Tiki-apoa from the earth (limestone clay) (Ellison et al. 2012; Te Hurinui Jones 1995).

\footnotetext{
${ }^{1}$ There is disagreement amongst scholars and Māori leaders alike as to whether Io existed in Māori societies prior to contact with Europeans. Some scholars point to the existence of Io in the oral traditions collected by Te Whatahoro Jury from two Wairarapa priests (tohunga) Nēpia Pōhūhū and Te Mātorohanga. Others, including Māori scholar Te Rangi Hīroa (Peter Buck), argue that Io emerged following contact with Europeans and exposure to Christian teachings. By establishing Io as the supreme god of Māori, Hìroa and others argue, tohunga (and other members of Māori society) sought to reconcile their own religious beliefs (which included a pantheon of gods) with that of Christianity's single god (Buck 1950, p. 526).
} 
Tainui traditions tell the whakapapa of how the two ancestors (Tiki-iāhua-mai-i-Hawaiki and Tiki-apoa Whiro) begot Whiro, who produced the explorer Toi, and from Toi came Whatonga. At least 20 generations took place before the Tainui waka arrived in Aotearoa, and another 50 generations were said to have occurred since then. The critical point is that Māori (both pre-colonial and post-colonisation) saw themselves and all parts of the world as being direct descendants of the gods, who in turn sprung from Te Kore (the Void) and the Io (the parentless one, supreme being and original energy) (see Fig. 3.3: Whakapapa spiral). Every part of the universe was, thus, interrelated, and all relationships were organised through whakapapa (lines or layers of genealogical progression). Every person was an envoy and assistant to all those who came before themboth their human tūpuna (ancestors) and their ancestor-gods-back to their common source (Te Kore and Io); similarly, they were/are representatives and ancestors for future generations (Parsons and Fisher 2020).

The holistic system of thinking and knowledge, commonly referred to as Mātauranga Māori (Māori knowledge) and tikanga Māori (laws and principles), established and maintained a matrix of kin-centric relationships between all living and non-living actors (Ataria et al. 2018; Hikuroa 2016; Mead 2016). Included in this web of connections and overlapping rights and responsibilities were both humans and biota, biophysical and metaphysical entities, gods and ancestors. Māori groups were directed by their system of law (tikanga), decision-making authority, and a suite of fundamental concepts (Mead 2016). Key Māori principles, including tapu, mana, whanaungatanga, manaakitanga, tikanga, utu, tuku, and kaitiakitanga, are outlined in Fig. 3.4.

Within their complex, dynamic, and principled society, which was governed by tikanga, Māori developed and sustained ongoing and substantive ties with te taiao (the natural environment) of their rohe, which included their whenua (lands), awa (rivers), maunga (mountains), and repo (wetlands). Māori worldviews (which were multiple rather than singular due to the tribal nature of society but shared similar principles) were holistic and kin-centric wherein all things were interconnected together through whakapapa. They were linked to every part of their local taiao (environment) through their whakapapa (Collins et al. 2012, p. 323). Each maunga, awa, roto (lake), repo, and other features of the 


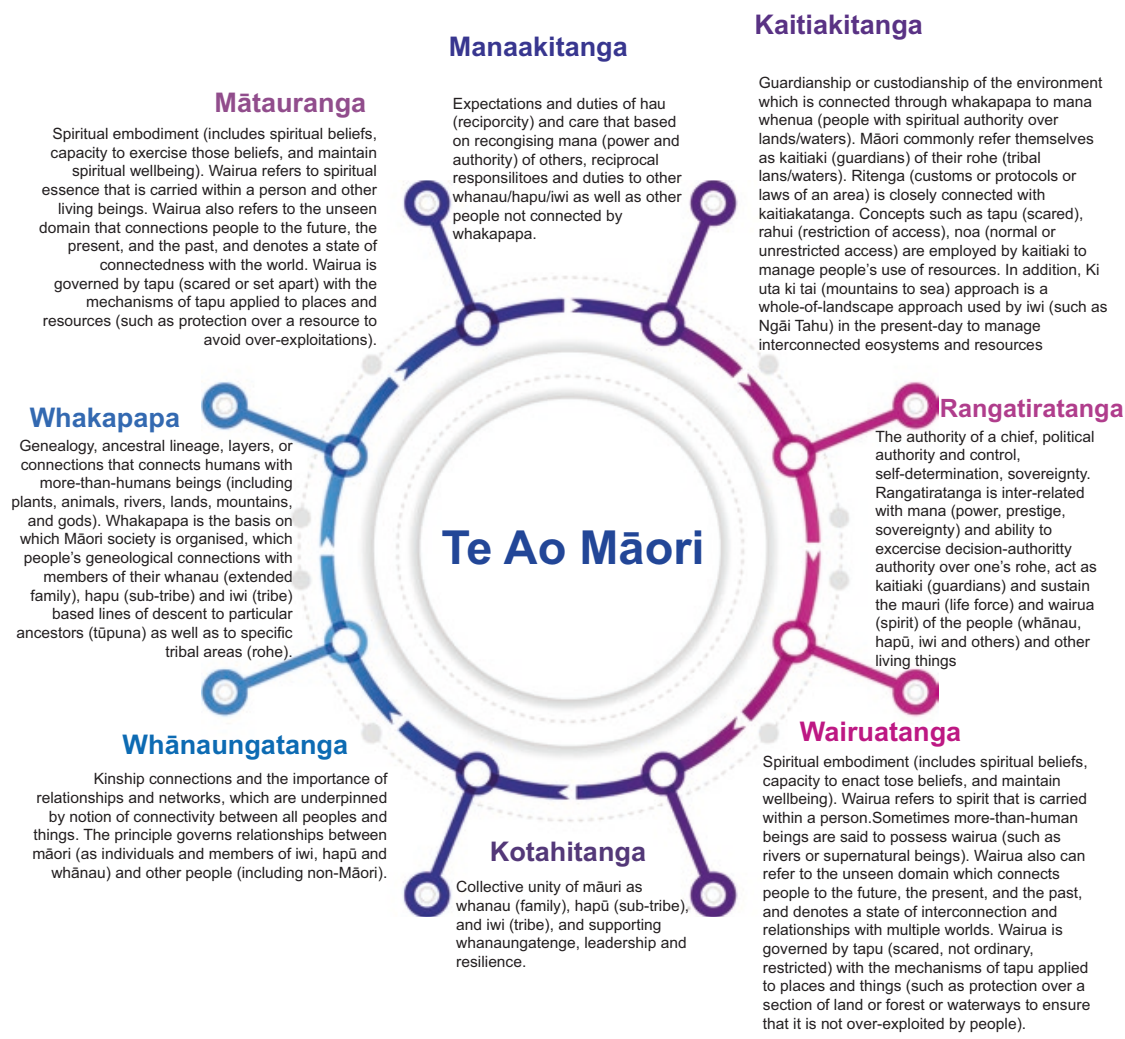

Fig. 3.4 Key principles and concepts of Te Ao Māori

landscape was a component of the web of whakapapa relationships that began with Io and Te Kore, carried on to the creation of the gods and all living beings, continued through the migrations of Māori ancestors from Hawaiki to Aotearoa, and maintained in every generation since then. Within the Waipā River catchment, as elsewhere in Aotearoa, the landscapes and waterscapes were also the source of people's cultural identities, and their collective health and wellbeing.

Just as Māori was linked to one another through their whakapapa, so too were they connected to whenua, bodies of wai (water), biota, and other parts of the taiao. Whenua was the source of identity and life, with whakapapa creating a sense of place wherein each person lived and felt a 
sense of belongingness to their rohe. Bodies of wai were similarly crucial to Māori lives, livelihoods, and identities, with ancestral connections to specific rivers, streams, lakes, springs, wetlands, lagoons, estuaries, and seas forming essential parts of people's embodied waterscapes which sustained their lives (providing them with drinking water, foodstuffs, medicines, and other vital resources) but also their identities. When the people left the Tainui waka and travelled the region giving names to the physical features of lands and waterways, they were making claims to those areas and establishing their authority over it (in this way, naming was the equivalent of the European custom of raising a flag to take possession of a foreign land). Each subsequent generation of Māori re-articulated their ancestors' relationships and established their ones, which were transmitted down through names, songs (waiata), sayings (pepeha and whakataukī) and other kōrero that linked their tribal territory to those of important tūpuna (Belgrave et al. 2011, p. 59; Collins et al. 2012, pp. 109, 114; Durie 1994, pp. 61-63; Tauriki et al. 2012, pp. 120-121). Through such methods, individuals were able to understand and describe in-depth their ancestral linkages with their rivers, mountains, flora and fauna, and other parts of the environment. Moreover, they were able to understand the complex network of occupation and usage rights they (and their whanau and hapū) possessed, and how the different parts of their landscapes and waterscapes needed to be managed (according to tikanga and the various principles, most notably kaitiakitanga).

\section{Waterscapes of the Waipā}

Te Ao Māori and ways of life for different Māori communities, before British colonisation, centred on the use of resources within their fisheries (freshwater, estuaries and marine) and forests, as well as horticultural cultivations (climate-dependent) (Anderson 2002; Anderson et al. 2012; Stokes 1988). The population, living as whanau and hapū, were concentrated along rivers and river mouths, beside lakes and estuaries-in environments that provided a myriad of flora and fauna to harvest.

Water plays a central role in Māori cosmological accounts. In one waiata (song), for instance, water materialises when Papa-tū-à-nuku and 
Ranginui are coupled together in an embrace. When their son, Tane Mahuta disconnected Papa-tū-ā-nuku and Ranginui, they cried for one another and expressed their loss and sorrow at their separation. The tears of Ranginui fell onto the land and created the lakes and rivers, which included the Waipā River (Salmond 2017). The tears of Papa-tū-ā-nuku rose as mists. From this cosmological account, freshwater was not something singular but rather dual. Water as groundwater, aquifers, and springs (which emerges from the ground) was classified as wai mā (clear and pure waters) and was used in practices to cleanse or purify (tapuraising practices/procedures). Water as rainfall was identified as something distinct as wai mangu (dark waters). These two waters together were known as wai rua (meaning two spirits or waters) that provide the life force for all living beings. Oral traditions tell how female and male ancestors' relationships were characterised by periods of intimacy and connection, and conflict and division. Their descendants could similarly take care of or undermine the hau ora (the energy or 'breath of life') of living beings (both physical and metaphysical), which includes both lands and waters (Salmond 2017, p. 300).

A wealth of historical, Māori oral traditions and archaeological studies demonstrate how the wetlands of the Waipā River catchment (and other freshwater systems around Aotearoa) were key locations where Māori whanau, hapū and iwi lived, gardened, fished, and sought refuge in times of conflict (Cromarty and Scott 1995; W. Shawcross 1968; Tauriki et al. 2012). Oral histories from Māori who affiliate to the iwi of Ngāti Apakura and Ngāti Maniapoto, whose rohe includes the area surrounding Te Awamutu, recount how their ancestors lived, managed and cultivated specific wetland-centred waterscapes. In addition to extensive kumara and taro cultivations, local hapū lived in kainga (villages) and pā located within the wetlands. Ngāti Apakura elders describe how their ancestors created Lake Ngāroto in the mid-eighteenth century through damming streams to create the vast expanse of water (Belgrave et al. 2011; Borell and Joseph 2012; Tauriki et al. 2012). Their ancestors built the island in the middle of the lake using large logs as the foundations (secured to the lakebed), over which they laid bundles of tree (mānuka) branches and reeds (rāupo), and soil. Over generations, the soil was slowly built up over the one-acre, until it formed a large mound that became the home of 200 
people (Borell and Joseph 2012; Tauriki et al. 2012). Archaeological studies support these oral traditions and identified at least five pā located around the lake edge as well as those constructed on an island (Cassels 1972a; Internal Affairs Undated; Pick 1967; W. Shawcross 1968). Significantly, the island pā site was, archaeologists, suggest, continuously occupied by Māori from its creation until residents were forced to flee during the 1863 invasion (Belgrave et al. 2011, pp. 36-41; Tauriki et al. 2012). The continuous occupation was notably different from typical Māori practices of using pā only intermittently (seasonally or during times of warfare) and highlights the capacities of the lake and surrounding wetlands to provide consistent supplies of resources (which did not require them to relocate to other places to access food resources as was the standard practice amongst Māori communities). Archaeological evidence from elsewhere in the Waikato region records the existence of numerous wetland pā, artefacts including waka, buildings, and horticultural tools, which demonstrates the continued occupation and resource usage within the area (Boswijk and Johns 2018; Hogg et al. 2017; Lorrey et al. 2018; Pick 1968).

Wetlands like Ngāroto were significant resource extraction spaces, not limited to mahinga kai (food gathering sites) (Anderson 2016; Cassels 1972b; Kennedy 2017; Robb 2014; Tāne 2017, p. 47; Tauriki et al. 2012). A diversity of flora was harvested: harakeke (Phormium TenaxNew Zealand Flax) was used to make rope, baskets, mats, and clothing; kuta (Elochiris sphacelata - bamboo spike sedge) used for insulating and weaving; raupō (Tayphia Orientalis) for thatching, construction, and food (the pollen could be used to make a form of bread); besides, other sources of food included the berries of Kahikatea and Matai trees, fungi, and fern-roots (Forster 2012, pp. 39, 121-145; Parsons and Nalau 2016; Pond 1997). Numerous fauna were also harvested from wetlands, notably prized tuna (Anguilla spp.- - short and long-tailed freshwater eels), inanga (Galazias spp.- - whitebait), and koura (freshwater crayfish-Paranephrops planifrons), as well as numerous fish, shellfish, and aquatic bird species (Barrett 2012; Collins et al. 2012; Downes 1918; Tauriki et al. 2012). Crops were grown on higher areas of land; traditionally taro (Colocasia esculenta) and kūmara, and later with the arrival of Pākehā, wheat, potatoes, and other crops. 
Ngāti Apakura also describes how Lake Ngāroto was the home of the atua Uenuku (god of rainbows), who was brought on the Tainui waka on its journey from their ancestral home of Hawaiki to Aotearoa in the form of stone (Borell and Joseph 2012). In Ngāti Apakura, Ngāti Maniapoto and Waikato/Tainui oral traditions, Uenuku was also considered the god of food gathering (Borell and Joseph 2012; Davidson et al. 2011; Ellison et al. 2012; Marsden 2003; Smith 2011; Taumoefolau 1996; Tauriki et al. 2012). Ngāti Apakura elders recalled how historically (prior to 1863) before anyone undertook fishing activities they would seek to satisfy Uenuku. The first eel or fish caught would be given to Uenuku as a way to ensure the health and wellbeing of themselves (and their whanau and hapū) as well as their environments (to maintain the mauri or life force of all beings that made up their rohe) (Borell and Joseph 2012).

Māori from the Waipā catchment describes the wealth of food sources that their tūpuna were able to access from the lands and waters (Waitangi Tribunal 2018, pp. 43-44). The network of land, water, and wetlands of Waipā Valley (where the Waipā River join with the Waikato River) was known as the "great food bowl". Similarly, Te Kawa wetlands were referred to as the "pātaka kai" (food store) of tangata whenua (Waitangi Tribunal 2018, p. 44). Pureora Forest (east of Te Kuiti at the headwaters of the Waipā River) and other forested areas were essential sites for harvesting berries and birds, and all the rivers, streams, and lakes of the region provided plentiful supplies of tuna (Belgrave et al. 2011; Cunningham 2014; Tauriki et al. 2012).

The capacities of people to take care of freshwater and land, sea and wetlands, people and other living beings depended on their whakapapa relationships to specific landscapes and networks of exchange between whānau, hapū and iwi. During different times of the year, groups travelled across the land, along the rivers, and sea, and followed the pathways of their ancestors (Anderson et al. 2012). Their knowledge of their ancestors allowed them to harvest specific biota in specific places at particular times of the year; indicators of seasonal change such as cloud formations and phenological signs (flowering and fruiting of plants, the behaviour of animals) were used to inform people's livelihoods (digging fern root, planting and harvesting taro and kūmara crops). 


\section{Waste and Water: The Two Should Never Mix}

Historically, Ngāti Maniapoto communities (like those of other iwi) within the Waipā River catchment relied on their ecosystems for their physical and spiritual wellbeing (as we outlined in Chap. 2). They harvested food to eat and collected water to drink from their local environments, and therefore those resources needed to be both healthy and plentiful. As the size of communities grew (during the Classic Māori period the 1600s-1800s) and fortified settlements (pa) became more commonplace, Māori developed a range of comprehensive governance and management strategies, which were designed to regulate and mitigate the negative impacts of human activities on the environment that included material and metaphysical (more-than-human) actors (Anderson et al. 2012; Ballara 1998). Strategies included: rāhui, a temporary restriction placed by a chief on people accessing and using a particular area, which included a prohibition on harvesting activities (could be placed following an accidental death or because a need to conserve resources); as well as practices surrounding tapu (sacred, prohibited, to be set apart, not ordinary) and noa (usual, ordinary, safe, not subject to restrictions) (Bambridge 2013; Best 1904; Mead 2016). An array of regulations were rigidly enforced about how each different types of waste products (food, human, animal, and other material waste) were dealt with, which depended on the source of the waste (shellfish middens, wood shavings from carvings, human effluent, hair and nail clippings, disposal of the dead and so forth). Early Pākehā (explorers, missionaries, and researchers) noted that Māori did not use any type of manure on their cultivations and missionary attempts to use "such substances on their kitchen gardens [Māori] bought against them ... a charge of high opprobrium" (Best 1931, p. 131). It was subsequently reported (by Firth) that Captain James Cook praised the way Poverty Bay Māori managed waste products and contrasted it to European practices at the time (Firth 2012, pp. 94, 312-314). Traditionally, then, Māori kainga, marae, and pa complexes ensured that there were strict zones of activities designed to uphold Māori values (tapu and noa) and protect people and their wider environment (including their more-than-human kin) from harm caused by 
contamination of waste products. Māori waste management practices centred on the physical separation and designation of certain areas for specific waste products (human waste like faeces, urine, and menstrual waste, the washing of clothes and bodies, food waste) (Mead 2016; Pauling and Ataria 2010; Waitangi Tribunal 1993).

Areas for waste disposal were kept spatially segregated from important spaces related to sustaining the community (such as food cultivation and harvesting, food preparation, and the collection of drinking water supplies) as well as significant activities and people (Mead 2016; Pauling and Ataria 2010). Traditionally, this was done by ensuring that the toilet, kitchen and living areas within a Māori settlement were physically detached from one another, as well as the deliberate placement of a toilet on sloping land or beside a cliff, and by demarcating different areas of waterways for bathing, harvesting kai, and collecting drinking water (Ataria et al. 2018; Marsden 2003; Mead 2016; Pauling and Ataria 2010).

The vital principle of tapu underpinned waste management strategies. Tapu translates into English as something sacred, prohibited, special, not ordinary, and something that needs to be set apart; the antithesis of tapu is noa that refers to normal, ordinary and unrestricted. Tapu was (and still is) of a temporary (such as a rāhui or temporary ban on harvesting) or intrinsic nature (such as a burial ground and human waste products). However, all things in the world are considered to possess tapu, inherited from atua and holding considerable (spiritual) power (Mead 2016). Tapu provides the spirituality and metaphysical connections between people, plants, animals, whenua, awa, and taiao. When different types of tapu interact, the results can be destructive (such as illness or death). So, systems of control are designed to manage these interactions to achieve positive outcomes (maintaining good health of a community). In the case of human waste and body parts (which are considered very tapu) waste management practices are designed to protect the tapu (sacredness) and mana (power) of human beings, awa, and whenua. However, following colonisation, the established system whereby Māori managed waste products were no longer disrupted and displaced, as communities were dispossessed, migrated (voluntary or forcibly or a combination of both) to new areas, and new modes of living adopted. Yet, Māori understandings of waste and the need to ensure the principle of tapu were maintained 
persisted into the twentieth and twenty-first century. In the second half of the twentieth century, as we later examine in Chap. 5, Ngāti Maniapoto iwi members campaigned against local government authorities practices of discharging treated human waste (from town sewage treatment plants) into the Waipā River and its tributaries on the basis that human waste (even if handled by scientific methods) was still tapu. Accordingly, all water became polluted once it was in contact with human waste, and iwi fought for alternative modes of waste disposal to be implemented (which were more in keeping with their tikanga).

\section{Te Ao Māori at the Time of European Contact}

Broadly, Aotearoa New Zealand history, over the last two hundred plus years, is reflective of broader processes of European imperialism and colonialism around the globe, which involved phases of contact, colonisation (using military, socio-cultural, legal, and ecological mechanisms), and development. The first recorded contact between Māori and Pākehā occurred in 1642 when the Danish explorer, Abel Tasman, gave the islands the name Nova Zeelandia (New Zealand). In 1769, nearly 130 years later, an English explorer (Captain James Cook) and his crew's supposed 'discovery' of Aotearoa heralded the first wave of European imperial activities from the 1790s onwards; sealers, whalers, and traders arrived (namely from the Australian colony New South Wales) seeking new resources to exploit (see Fig. 3.5).

Pākehā encountered a socio-cultural landscape made up of heavily mountainous terrain with a temperate climate, extensive and dense forests teeming with birdlife, and a vast indigenous Māori population (estimated to be number 80000 in 1840) (Stokes 2013). The vast majority of Māori lived in the northern half of Te Ika-a-Māui (North Island), which possessed a climate that was warmer and better suited for Māori horticultural techniques and plants. In addition to the cultivation of kūmara (Bassett et al. 2004; Unknown Author 1902), Māori living in warmer regions with access to sufficient freshwater supplies were able to grow taro (Ban 1998; Irwin 2013; Matthews 1985), which included Māori hapū 


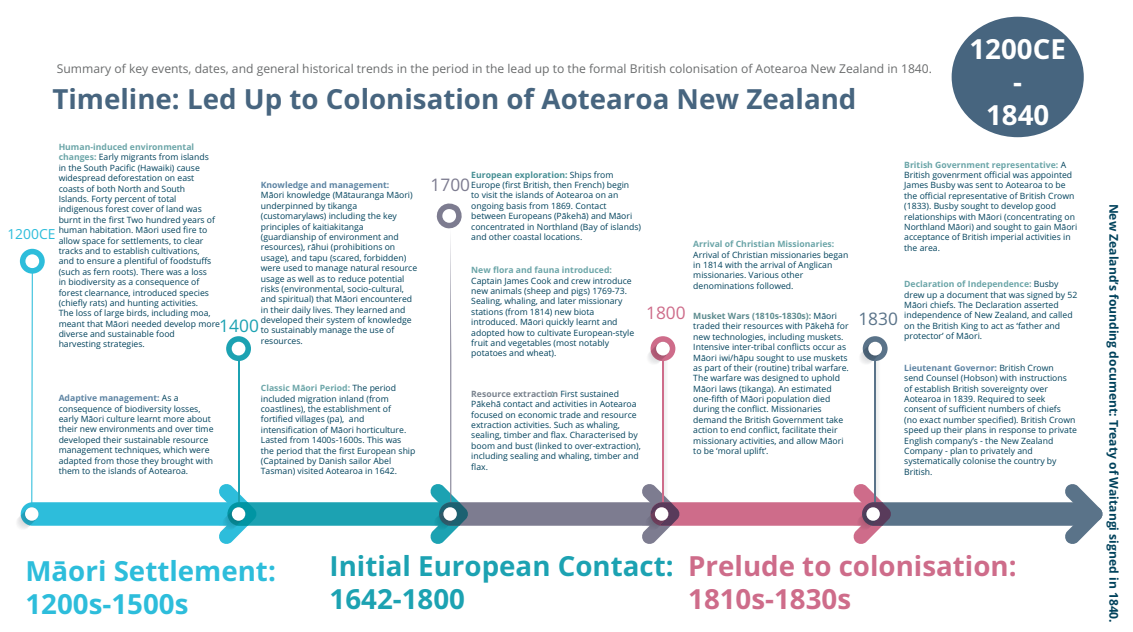

Fig. 3.5 Timeline-Lead up to colonisation

living in floodplains of the Bay of Plenty and the Waikato (Best 1930, 1931; Hargreaves 1959; K. Shawcross 1967).

When Pākehā first began to visit, trade, establish relationships with and make homes with and alongside local hapū in the Waipā (like elsewhere in Aotearoa), they did so under the watchful eye and with the explicit permission of local rangatira. Waipā iwi initially engaged with new arrivals (most notably new biota, knowledge, and technologies) with enthusiasm. It sought to incorporate new plants and animals, agricultural production technologies (flour mills and ploughs), clothing and trading relationships. Māori subsistence-based horticultural operations were extended and modified to engage (to some extent) with the capitalist marketplaces of Pākehā, all. At the same time, Māori sought to maintain their values, knowledge and reciprocal relationships (based on whakapapa and occupancy) with their whenua, awa, maunga and other taonga. Hapū along the Waikato and Waipā Rivers became the major suppliers of agricultural product to the fledgling Pākehā settlement, Auckland; Māori was well on their way to being agricultural entrepreneurs as they shipped their crops and other goods by sea to settlers living in towns in Aotearoa, the Australian colonies, and California. 
Throughout the first three decades of the nineteenth century, in addition to the arrival of sealers and whalers, there was a growing demand for flax (the fibre of which was used to make rope and sales) and timber (for shipping masts) from Pākehā who were visiting Aotearoa's shores, including Britain's Royal Navy vessels (Belich 1996; Anderson et al. 2014, pp. 179-181; Petrie 2013). These activities brought clusters of Pākehā (sailors, traders) to stay in Aotearoa for months or years at a time, near Māori settlements located along the coast of both islands, including in the Waikato (at Kāwhia and Waikato Heads) as well as the Bay of Plenty (Whakatāne, Maketū, Matatā, Ōhiwa, and Tauranga) (Boulton 2007; Cummins et al. 2004; Anderson et al. 2014, p. 180). Māori was rewarded for their involvement in procuring flax and timber, which was often physically demanding and sometimes dangerous work. Work was typically organised along hapū lines, as was the majority of Māori economic activity in this time period. The rangatira acted in the role of the subcontractor, who agreed to the terms of work relationships with Pākehā, supervised the work, and received payment, which was distributed amongst the hapū members (Adams 2013; Petrie 2013). While Pākehā presence was restricted to the coastal areas of the Waikato and the King Country in the 1830s, hapū from Waikato and Waipā catchments were harvesting flax that they transported to the coastal kainga of Kāwhia, and Waikato Heads to trade with Pākehā. The flax trade continued to be a feature of the Waikato economy until the start of the twentieth century (Francis 2011).

\section{Divergent Understandings of Land: Rights Versus Ownership}

There was no concept of owning land, water, or any other resources in Māori society, in marked contrast with European cultures. When Māori engaged in land transactions with Pākehā, they did so through their cultural lens. Rights to land, water, forests, and other resources were, in Māori culture, collective and highly fluid. Individuals could inherit usage rights to certain areas of land or a river through their parents (both 
paternal and maternal lines). Rights were shared between different whanau, hapū, and iwi; usage rights often overlapped, with groups able to visit and harvest resources but only from a particular area or at a specific time of year. Often there were disputes between hapū, which created conflict. The fluidity in defining and policing boundaries was further complicated with the arrival of Pākehā, who first sought Māori timber and flax, and later land. Pākehā brought with them their ways of thinking about and managing land, which was premised on the idea that all land boundaries were fixed and final, and that land could be owned (and by extension bought and sold).

In the late 1820 s and throughout the 1830 s, Pākehā began to seek to purchase land from Māori including in the western harbours of the Waikato region and the river mouths and concentrated on identifying one person who was the "owner" of the land and who could sell them the land (Cummins et al. 2004; Cunningham 2014; Hammer 1991; Luiten 2011; Schnackenberg 1935). In doing so, Pākehā overlooked (frequently deliberately) the complex and dynamic layers of Māori rights to land and resources and imposed their own cultural and legal traditions. Māori similarly engaged with Pākehā for their ends using their worldview. An organising principle of Māori society was the pursuit of mana, whereby people (specifically rangatira) sought to gain and maintain mana through actions. When a Pākehā found to form an agreement (for trade, land or other resources) with one chief (and associated hapū) it served to enhance the mana of that rangatira (and hapū) and diminished rival rangatira and hapū who were not a party to that agreement. Accordingly, many rangatira signed written documents (deed of sale), which transferred ownership (a concept that had no equivalent in Te Reo Māori) of areas of land and received small payments (often in the form of goods). For hapū, the provision of land to Pākehā was based on the understanding that missionaries and merchants would form long-standing and mutually beneficial relationships with Māori. Broader historical scholarship on Māori-Pākehā highlights how, in the period prior to the Te Tiriti o Waitangi/Treaty of Waitangi (1840), Māori communities throughout Aotearoa made land available for Pākehā to live on and use in the context of continuing reciprocal relationships (Brookes 2016; Wanhalla 2015, 2017). 
Rangatira expected that Pākehā traders, for instance, would give regular gifts to them (such as weatherboard houses, small boats, tools, and clothing) in return for rangatira giving them the right to stay in the chief's area of authority. Different interpretations of these arrangements existed between Māori and Pākehā. For instance, whaling stations were on land that Pākehā perceived they had "purchased" from Māori. In contrast, rangatira generally interpreted that Pākehā had given them a tuku (gift) in exchange for the rangatira allowing whalers the right to occupy their tribal territory (Anderson et al. 2014, p. 181). The gifts were similar to a form of rent paid to rangatira in return for rangatira giving whalers the right to occupy land as well as supplying labour for whaling operations. Similar arrangements existed for embryonic timber, flax, and horticultural activities (first in the Bay of Islands, and later elsewhere in Aotearoa including Waikato). Vast supplies of food (specifically potatoes) began to be grown by Māori for barter and trade with Pākehā, which generated food surpluses (which were previously not common) and different rangatira organised large hui to display and demonstrate their mana (Anderson et al. 2014, p. 181).

Māori communities, particularly on the western harbours of the Waikato and King Country, were able to expand the quantity and diversity of goods (flax and food) which they could produce and ship to expanding towns (such as Auckland and New Plymouth, and Sydney and Melbourne) and in doing so generate wealth and enhance their mana. When intimate relationships between European men and Māori women resulted in the growth of "half-caste" children, many hapu simply viewed the land on which each family lived remained entrusted to the Māori community (Grimshaw 2002; Paterson 2010; Stevens and Wanhalla 2017). The rights to occupy the land would transfer from the Māori woman to her children. Adequately, the community considered that the Pākehā man held only a right to use the land so long as he stayed in the community (Boulton 2007). Such rights could not be transferred to someone else outside the community; Māori was determined to retain their mana and rangatiratanga. Despite their engagements with Te Ao Pākehā, they remained thoroughly connected and living within Te Ao Māori (Petrie 2013). 
Customary Māori governance arrangements were collective and involved different people within hapū acting together through tribal structures, which included rūnganga (tribal councils) and hui (Ballara 1998; Mead 2016). Members of hapū were influenced by the views and decisions of their rangatira; however, people did not restrict their views to what their rangatira thought. Indeed, while rangatira possessed the ability to shape any agreements reached within and between hapū, they did not have cohesive power over their people (that is "the ability to make and ensure compliance with unilateral decisions") (Anderson et al. 2014, p. 182). Rangatira was required to gain the support of their hapu members, and decision-making for Māori was a collective rather than individual process (Ballantyne 2012; Belgrave 2017; Belich 1996; O’Malley 2017). Implicitly, there was an expectation that all significant decisions and agreements would be made following in-depth discussions within the home (amongst whānau members) and on the marae (between members of the hapū) (Salmond 2018). Once a decision was made, it was rangatira who were held responsible for the choice and its consequences (be it good or bad). Accordingly, when taking part in negotiations with Pākehā, rangatira often added a requirement that they needed to take the proposal or decisions back to their hapū for their agreement (Anderson et al. 2014, pp. 180-182).

Christian missionaries began to establish mission stations around the western harbours of the Waikato region (Whaingaroa/Raglan, and Kawhia) and along the Waikato, Mokau and Waipā Rivers in the mid-1820s. In 1834, missionary John Morgan arrived at Mangapouri, located where the Puniu River joined the Waipā River and took up residence. In January 1841, John Morgan took over the mission station at Ōtāwhao (present-day Te Awamutu), which he headed from 1841 to 1863. Morgan saw the rise of Māori economic development by local hapū (O'Malley 2013, 2016). In 1863 (in the lead up to the Waikato Wars), just before the British invasion of the Waikato, Morgan fled after it became known by Māori that he was spying on them on behalf of the British.

The spread of Christianity complicated political mechanisms and tikanga because becoming a Christian (a mihinare) meant Māori were required to observe new rituals and worship a new atua. It also required 
taking up new codes of personal and inter-personal behaviour that differed from traditional forms of conflict management (such as the practice of taking utu-revenge-which was discouraged under Christian teachings) (Anderson et al. 2012; Waitangi Tribunal 2018). The advice of missionaries was sought for how to resolve conflict and regulate conduct within and between individuals, whanau and hapu (such as who should pay for damage to crops and what the punishments should be imposed if someone committed adultery). As more and more Māori became Christianised in the 1820s and 1830s, missionaries sought to ensure that their congregations followed their codes of conduct (law-ture) and rangatira tried to ensure that new laws were balanced with old (tikanga) (Ballara 1998). For rangatira for the presence of Pākehā visits and economic activities brought numerous gains to them and their hapū, but also brought with them new infectious diseases. These diseases included measles, influenza, syphilis and tuberculosis, which contributed to a sharp demographic decline amongst the Māori population in the mid-tolate nineteenth century (Pool 2015).

\section{Lead up to Colonisation: 1830 s}

In the late eighteenth and early nineteenth centuries, the British government in London showed little interest in Aotearoa as a colony after the costly experience of the American colonies revolt (Anderson et al. 2014; O’Malley 2013; Orange 2015). The empire was already substantial, and the British government was determined to maintain and guard its colonial rule of the Indian sub-continent, parts of the Caribbean as well as the newly created Australian colonies. Thus, British wealth could be better ensured by "free trade" rather than by acquiring more colonies in the Pacific. Indeed, five decades earlier, Britain rejected Aotearoa as the site of a convict settlement due to the perception that Māori culture was too warlike and likely to violently oppose any British intrusions (leading officials to establish the convict settlement in Botany Bay, Sydney, New South Wales). However, as British subjects were continuing to visit and move to Aotearoa, the British government increasingly recognised in the 1820 s and 1830 s that it could not ignore Aotearoa entirely. 
After years of individual Māori and missionary protests to British colonial officials about the bad behaviour of Pākehā in Aotearoa, the Governor of New South Wales decided that British authority in Aotearoa needed to be strengthened by sending a colonial official. The "British Resident", James Busby, arrived in the Bay of Islands in 1833 with the instructions to cultivate influence amongst rangatira and promote a "settled form of government" and a system of law that would allow Māori courts to manage conflicts (Anderson et al. 2014, p. 184; Stirling 2016). The shift in British Crown policy from 'free trade' to the formal colonisation of Aotearoa can be traced back to (in part at least) the work of Busby and the creation of the Declaration of Independence (He Whakaputanga o te Rangatiratanga o $\mathrm{Nu}$ Irene).

\section{Declaration of Independence}

James Busby sought to foster cordial relationships between the British Crown and Mãori (specifically those in the Bay of Islands region) and prompted the idea of a centralised Mãori government (more alike to those of Britain). He drafted the Declaration of Independence of the United Tribes of New Zealand (He Whakaputanga o te Rangatiratanga o Nu Irene), which was translated into te reo Māori by missionary Henry Williams, in the hope it would form the building blocks for a formal Mãori government (beginning with rangatira in the Bay of Islands). On 28 October 1835, thirty-four rangatira signed the declaration and signatures continued to be collected until 1839; most signatories came from chiefs in the Bay of Islands; however, Waikato rangatira, including Te Wherewhero (from Ngäti Mahuta hapü part of iwi WaikatoTainui) also signed (Harris et al. 2014; Orange 2015; Waitangi Tribunal 2014). Busby prompted the idea that the British Crown could protect Mãori interests and take care of external problems (such as British or French traders who came to Aotearoa and breached Mãori rules). The declaration stated that sovereign power rested with rangatira in collective abilities and that rangatira looked to the English King (then William IV) to protect them against any attempts (such as French imperialism) to challenge their independence. The document also (in the te reo Mãori version) requested that Britain act as a parent ("matua") to their infant Mãori political state ("to matou Tamarikitanga") (Harris et al. 2014; O’Malley 2017; Waitangi Tribunal 2014). The declaration probably contributed to the emergence of Mãori 
participants' (who took part in discussing and signing the document) sense of being a collective cultural and political grouping (rather than individual hapu and iwi) (O'Malley 2017); however, for most Màori living within the Waipa catchment and elsewhere around Aotearoa (in 1835 and for the proceeding next decade or so after), their daily lives and the very nature of political decision-making within communities continued to be centred on long-standing tribal and hapu identities, values, and practices. The 1835 declaration did not provide any legal basis for British rule or facilitate British immigration or settlement in the country (O'Malley 2017; Stirling 2016), yet this was precisely what many Päkehà living in New South Wales, Britain, and Aotearoa wanted.

By the late 1830s, there were rising tensions between different groups of Māori and Pākehā within Aotearoa (specifically in the Bay of Islands) over land and authority. Land dealings of individual Pākehā and individual rangatira caused conflict within and between hapū (particularly in Northland) as different rangatira sought to maintain and extend their mana through signing land deeds with Pākehā (Anderson et al. 2014, pp. 188-189; O’Malley 2017). By the end of the 1830s, many rangatira (particularly in North Island) began to express concerns about Pākehā land dealings with Māori. In addition, wealthy entrepreneurs in Europe were attempting to purchase Māori land and establish private colonisation schemes (most notably the New Zealand Company led by Edward Gibbon Wakefield).

Busby and missionaries petitioned the British Colonial Office to incorporate Aotearoa into the British Empire, and in August 1839 the British Secretary of State for the Colonies (Lord Normandy) sent a government official to do just that. Lord Normanby issued detailed instructions to the official-Captain William Hobson-as to how he was to proceed, which included Maori approval for the cession of their sovereignty, the broad outline of the need for a treaty to be signed with Maori and the way in which existing purchases by Europeans were to be dealt with (Lord Normanby 1908) The instructions included a requirement that Hobson convinces some (but not all or even a majority) of Māori chiefs to sign a treaty, and that efforts were taken to protect Māori rights. Normanby's instructions drew on the language of the mid-nineteenth century British humanitarian movement, which sought to regulate the behaviour of 
settlers, protect Indigenous peoples from the worst excesses of colonisation (which was seen to include violence, alcoholism, gambling) and assimilate Indigenous peoples into British culture. Britain already employed such treaties in its dealings with some North America Native American and First Nations peoples (Attwood 2001, 2014; Belich 2009; Jones 2016; Parsonson 2017).

\section{Te Tiriti o Waitangi (The Treaty of Waitangi)}

Te Tiriti o Waitangi (The Treaty of Waitangi) was signed by the representative of the British Government (Captain Hobson), various English residents, and more than 500 Māori rangatira in 1840 (Orange 2015). Signatories included rangatira from Waikato-Tainui and Ngāti Maniapoto iwi. (Anderson et al. 2012; Orange 2015). Not all rangatira representing the hundreds of different hapu and iwi in Aotearoa signed the Treaty. The majority of rangatira who did sign the Treaty placed their signatures on the Mãori language version (Te Tiriti o Waitangi) rather than the English version (the Treaty of Waitangi). The Treaty recognised both the British Crown and Māori rights in the new colonial order, but there was a lack of clarity about what precisely both sides were signing.

There were significant divergences between the two versions of the Treaty (Fig. 3.6) (Jackson 1993; Orange 2015; Waitangi Tribunal 2014). Both versions of the Treaty contained four parts: a preamble, three articles, and a postscript (see Fig. 3.6). The objectives of the Treaty were outlined in its preamble: the British Crown was to establish a government to protect Māori and Pākehā interests in Aotearoa and centred on the overarching principle (in both Māori and English language versions) on a partnership between the Crown and Māori iwi (and by extension two cultures: Pākehā and Māori) (Tawhai and Gray-Sharp 2011). In Article Two of the Māori version of the document, rangatiratanga (chiefly authority) was acknowledged, and the Crown gave an assurance that it would be secured under the new partnership arrangement. From a Māori perspective, the Treaty kept chiefly authority well-maintained, with the inclusion of British laws and institutions added onto Māori tikanga (rather than the other way around) (Healy et al. 2012; Jackson 1993; Orange 2015; Waitangi Tribunal 2014). 


\section{Different articles, different interpretations}

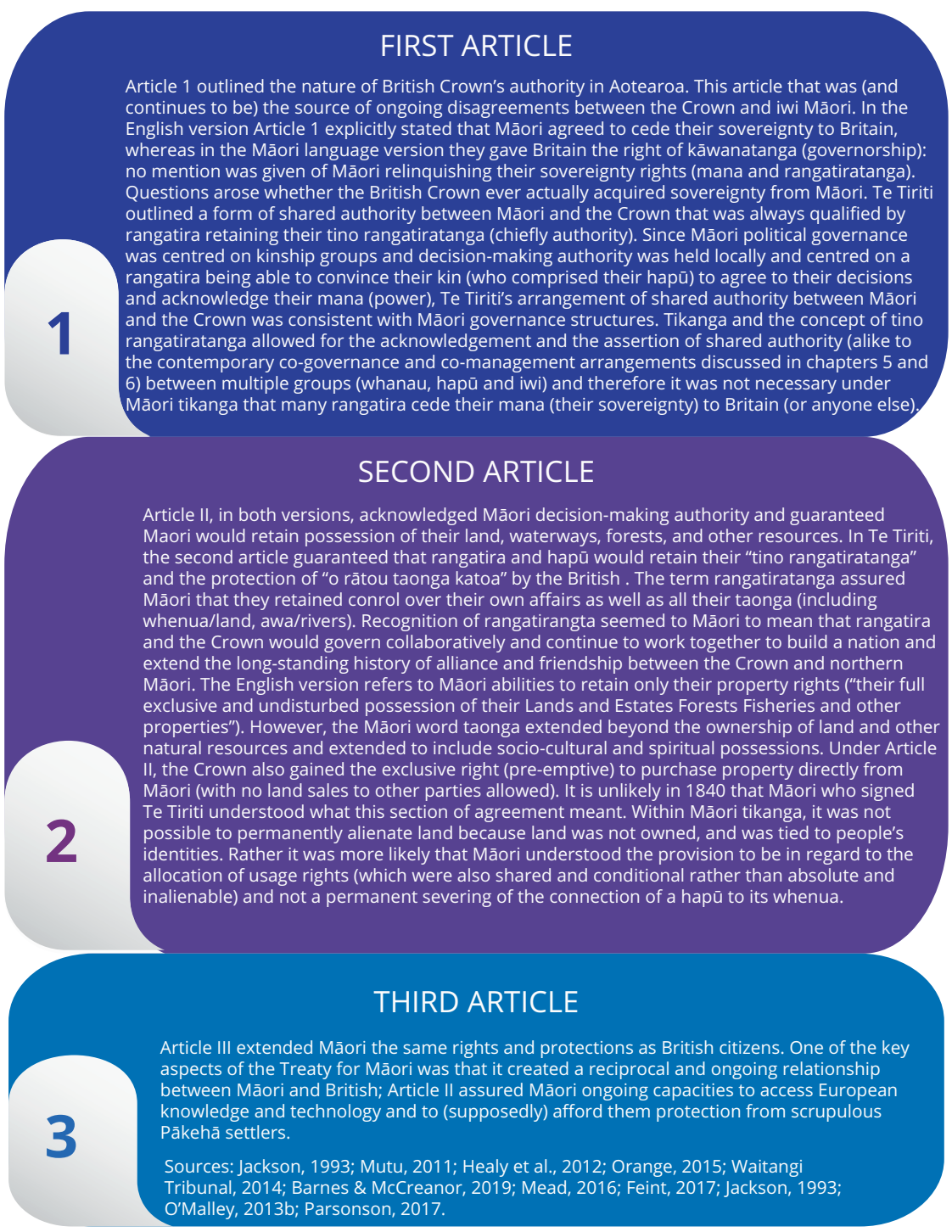

Fig. 3.6 Articles of the Treaty 
As pointed out by legal scholars, since the British Crown provided both English and Māori versions of the Treaty/Te Tiriti then the legal doctrine of contra proferentem (in use in 1840 and to the present-day) should be applied (Orange 2015; Suter 2014). The doctrine Contra proferentem (also known as the "interpretation against the draftsman") is a contractual interpretation which considers that, where an agreement, promise or term is ambiguous, the preferred meaning is the one that works against the interests of the party (the British Crown) who provided the vague wording (Chan and Fan 2018; Grammond 1994; Suter 2014). Accordingly, the correct meaning of Te Tiriti/The Treaty would be the Māori rather than British interpretations.

The Treaty presented to rangatira at Waitangi laid out a general statement of intentions and left the exact details of the nature of the partnership arrangements between Māori and the Crown undefined. The records of the oral discussions that took place during negotiations are few and far between. Since Māori society was traditionally a verbal rather than written culture, and important decisions were made by debates and discussions amongst rangatira (and hapū members), the absence of accurate records of what was said by rangatira about the Treaty and how Hobson and other British responded means we lack a full understanding of how Māori interpreted the Treaty. The limited, highly incomplete, records (written by missionaries, officials and local Pākehā settlers) indicate that Māori rangatira who met on 5 February clearly understood that they were faced with an important decision. Many rangatira spoke of their fears that they would lose their independence and be nothing more than slaves of the Governor (some reportedly stated that they did not want to end up like Australian Aboriginal peoples "having to break stones on the road") (Anderson et al. 2015, p. 203). Other speakers raised the issue of land dealing. They demanded that British Resident Busby and missionaries in the Bay of Islands return to the land they had initially purchased from Māori as they never intended to lose their land rights permanently.

While growing debates occurred within and between Māori and Pākehā communities about how and where British law and order was to be introduced, how it reconciled with "rangatiratanga", and what the new 
arrangements for the government were to be, for many Māori such debates were removed from their daily lives. Within the Waikato and Waipā catchments, Māori communities enjoyed a period of growing prosperity and productive trade with Pākehā. Indeed, for much of the 1840s and early-to-mid 1850s Pākehā settlers (notably the growing settlement of Auckland) depended heavily on iwi from the Waikato and Waipā river catchments for their necessary supplies.

\section{Historical Context: The Invasion, Raupatu (Confiscation) and Alienation of Whenua 1863-1885}

While the Te Tiriti o Waitangi/Treaty of Waitangi, signed by representatives of various Māori iwi and the British government in 1840, was meant to guarantee the protection of Māori land and natural resource rights, colonial officials did not honour the terms of the Treaty. The settler-led colonial government actively sought to appropriate Māori land and limit the abilities of Māori to exercise rangatiratanga over natural resources using the military, financial, and legal mechanisms (see Fig. 3.7: Timeline of key historical events). Colonial officials and settlers repeatedly expressed their desires to acquire the whole of the floodplains of the Waikato and Waipā rivers for Pākehā settlement at the same time as various Waikato Māori iwi and hapū were forming a pan-tribal alliance (the King Movement-Kīngitanga) that opposed selling land to Pākehā and sought to retain Māori political authority (rangatiratanga) over their whenua, awa, and other taonga including the wetlands. The Crown considered such efforts as acts of rebellion against the British Crown and used military and later legal mechanisms to undermine Māori political sovereignty, land tenure arrangements, and relationships with their whenua and awa (New Zealand Government 1865; Unknown Author 1864).

In the Waikato district, the appropriation of Māori land and waterways came first through military actions. Between July 1863 and April 1864 , British military forces, (consisting of 12,000 imperial troops, 4000 


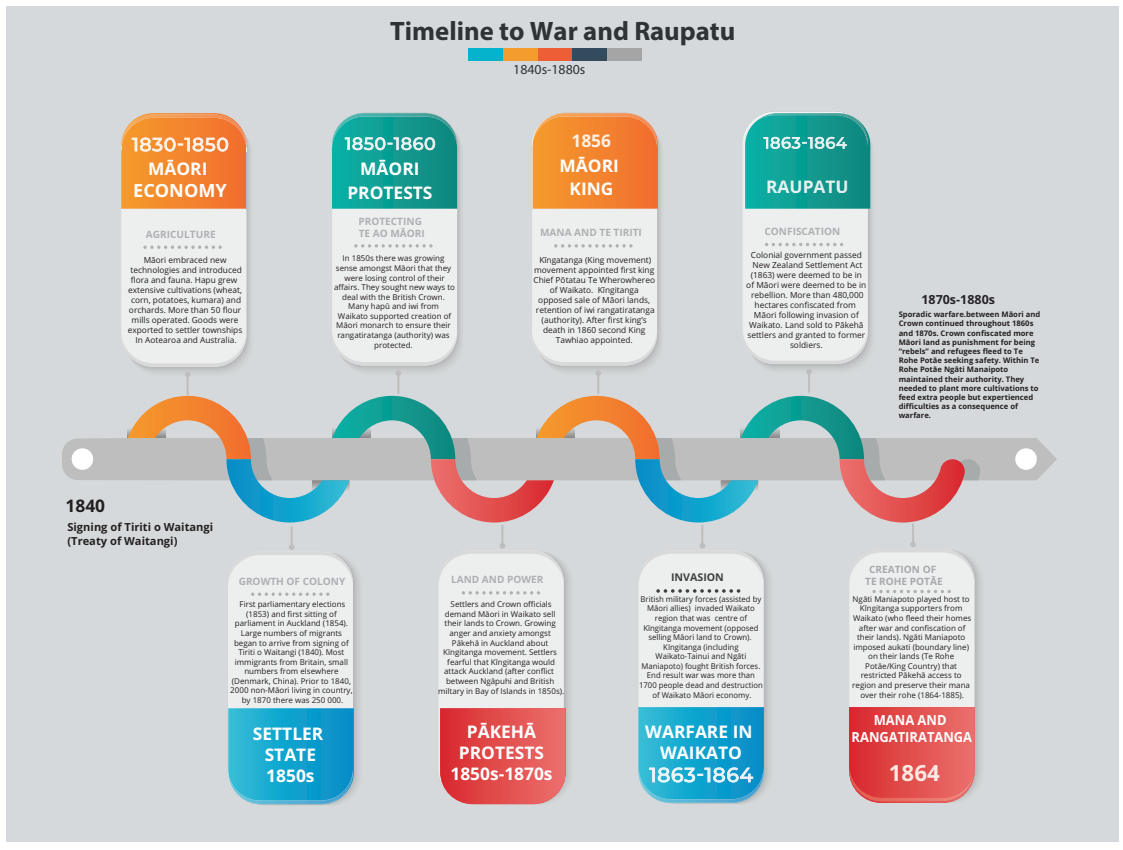

Fig. 3.7 Timeline of key events in Waipā 1860s-1880s

colonial soldiers and several hundred Māori tribal allies fighting against 5000 part-time Kingite soldiers), invaded and occupied the Waikato district (Belich 2015; O'Malley 2016). The result of the Waikato War was the death of approximately 1700 people, as well as the destruction of Māori economies. After the war, villages and crops were ruined, flour mills were burnt, and livestock looted. In 1865, the colonial government announced the confiscation of 485,000 hectares of land from Māori communities in the Waikato, including a large portion of the lower reaches of the Waipā River. The confiscated lands were allocated to Pākehā settlers. Members of Waikato-Tainui iwi (who supported the Kinngitanga movement) sought refuge with their kin, Ngāti Maniapoto, in the area south of the Pūniu River, which became known as Te Rohe Pōtae. Te Rohe Pōtae remained under the rangatiratanga of Ngāti Maniapoto until 1882 when iwi rangatira (leaders) (see Fig. 3.8: Photograph of Ngāti Maniapoto chiefs) agreed to allow the colonial government to begin to 


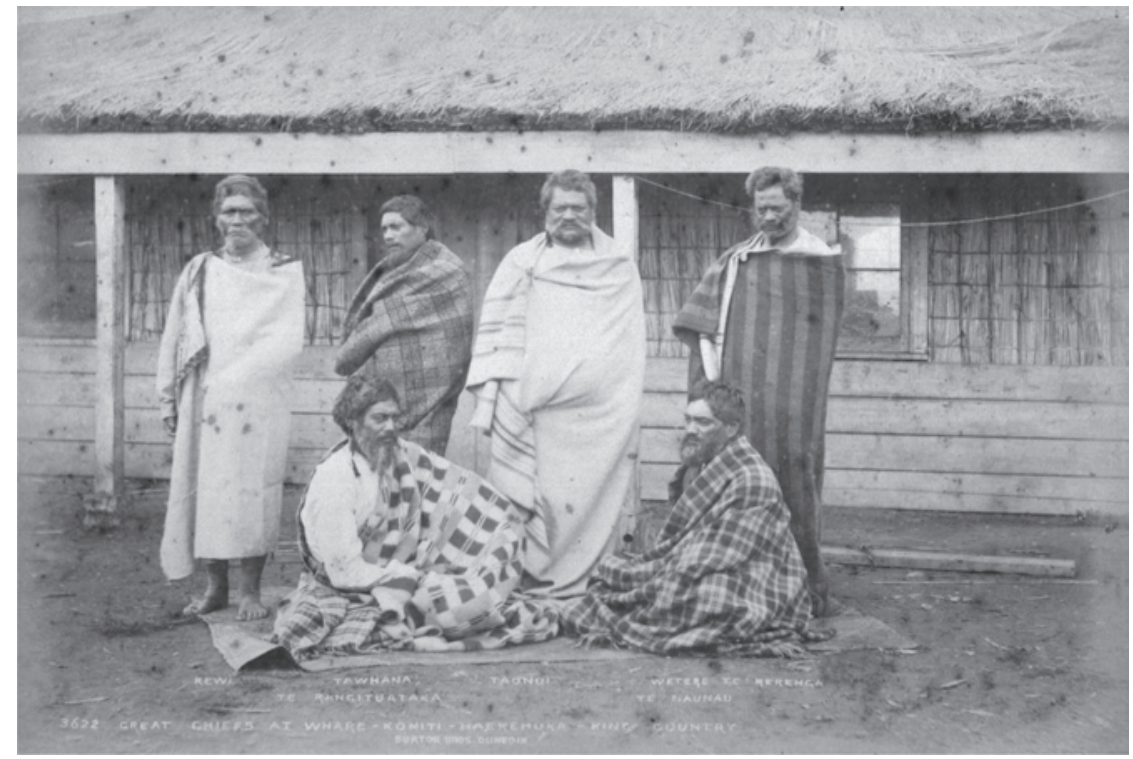

Fig. 3.8 Group of Ngāti Maniapoto rangatira (chiefs) photographed at whare komiti (committee meeting) at Haerehuka, Rohe Pōtae (King Country) on 4 June 1885 by Alfred Burton. The meeting was to discuss whether to allow the Crown to construct a railway through their territory. Back row, from left: Rewi Maniapoto, Tawhana Tikaokao, Taonui Hikaka, Hone Wetere Te Rerenga. Front row, from left: Te Rangituataka, Te Naunau Hikaka. Source: Alfred Henry Burton (photographer), PA7-36-30. Alexander Turnbull Library, Wellington, New Zealand

construct a railway line (the "Main Trunk Line") through the area, which resulted in the area being 'opened up' to Pākehā settlers (Belgrave 2017; Waitangi Tribunal 2018).

With the commencement of works to construct the railway in the middle and upper reaches of the Waipā River, the loss of Māori land, access to resources, and accompanying decision-making authority occurred insidiously and cumulatively through the mechanisms of the settler-colonial law (legislation and the judiciary) rather than through acts of war (see Table 3.1: Land loss within Te Rohe Pōtae district) (Belgrave 2017; Williams 1999). Both military and legal means achieved the same ends: to severe the links between the Indigenous people and their rohe. One adopted abrupt and apparent methods to obtain it, the 
Table 3.1 Land loss within Te Rohe Pōtae district

\begin{tabular}{|c|c|c|}
\hline Year & $\begin{array}{l}\text { Percentage of } \\
\text { land area } \\
\text { held by Māori }\end{array}$ & Notes about alienation \\
\hline 1865 & 93.1 & $\begin{array}{l}\text { Government acquisition of Māori land prior to } 1865 \text { was } \\
\text { approximately } 6.7 \text { per cent of total land area (129 } 181 \\
\text { acres) within Rohe Potāe district (as defined by } \\
\text { Waitangi Tribunal Inquiry). The total area of land } \\
\text { alienated from Māori was } 7.9 \text { per cent. }\end{array}$ \\
\hline 1889 & 93 & $\begin{array}{l}\text { The Native Land Court's entry into the district in } 1886 \\
\text { was a major factor in establishing and accelerating } \\
\text { Māori land alienation. More than } 40 \text { per cent of land } \\
\text { within the district was alienated between 1889-1910. } \\
\text { Overall, the majority of the alienations was from } \\
\text { government purchasing ( } 97 \text { per cent). }\end{array}$ \\
\hline 1910 & 49 & $\begin{array}{l}\text { Between } 1910-1931 \text { the pace of land alienation slowed, } \\
\text { with Māori land holdings reduced to just under } 50 \\
\text { percent of pre-1840 levels in } 1910 \text {. Private acquisition } \\
\text { of Māori land was significant feature of the time } \\
\text { period. }\end{array}$ \\
\hline 1931 & 24 & $\begin{array}{l}\text { Pace of land alienation continued to slow, with Māori } \\
\text { seeking to retain what little land that remained within } \\
\text { the district. During the 1950s the local government } \\
\text { compulsory acquired Māori land (as well as non-Māori } \\
\text { land) along the Waipā River and its tributaries as well } \\
\text { as other river systems in the Waikato Region for flood } \\
\text { control works. The land was acquired ("taken") under } \\
\text { the Public Works Act. }\end{array}$ \\
\hline 1966 & 18 & Most land alienation in the second half of the twentieth \\
\hline 1975 & 15 & $\begin{array}{l}\text { century in Rohe Potāe is a consequence of Māori } \\
\text { seeking to convert (Europeanise) their Māori land title } \\
\text { (whereby each parcel of land is divided into shares held } \\
\text { by different members of a whānau) to freehold title } \\
\text { (individual owners). }\end{array}$ \\
\hline
\end{tabular}

other used slow insidious but still violent means. In particular, the operations of the Native Land Court (which commenced operations in Ngāti Maniapoto territory in 1886) involved blocks of Māori land going through a legal process to convert them from communally held (wherein usage rights were shared between whānau and hapū) into individualised land titles. The activities of the Native Land Court effectively continued where the land confiscations of 1863 had left off; for more details about 
the Native Land Court (defined by one scholar as an "act of war") see the works of historians including Judith Binney, Richard Boast, and David Williams (Binney 2001; R. Boast 2008; R. P. Boast 2017; Williams 1999). Once converted to individualised titles, Māori were frequently forced to sell their land due to financial necessity (to pay the high prices of court fees, government taxes, and costs of living). The central government acquired the majority of Rohe Pōtae land in this manner; the government were able to purchase Māori land heavily reduced prices and then on-sell the land to settlers at far higher prices.

On top of that, successive acts of parliament gave central government departments and local government bodies broad-ranging powers to acquire or fundamentally alter the characteristics of land and waterways in the name of 'development' and 'improvement', which included the drainage and destruction of the extensive wetlands of the Waipā River and its tributaries. Local government bodies (empowered by central government) authorised water- and land-scape remaking activities (draining wetlands, realigning rivers, building railways and roads, and removal of native vegetation). In doing so, government officials (deliberately and incidentally) ignored the rangatiratanga of iwi over their awa and whenua, and their responsibilities as kaitiaki (environmental guardians) to care for and maintain the mauri of the river, land, biota and their people. The concerns of iwi and their reflections back to the invasion, confiscations, and breaches of the Treaty illustrates a critical aspect of the Indigenous environmental justice theorising, which recognises the connection between past and present injustices.

\section{Conclusion}

In this chapter, we provided an overview of the histories and values of iwi and hapū living within the Waipā River catchment before and immediately following colonisation. The chapter presents the building blocks for readers to later understand the consequences of the settler efforts to radically remake Māori waterscapes and landscapes, and the negative impacts 
of those changes for iwi, hapū and whānau. Such historical analyses are often engaged to explain the emergence and significance of environmental injustices on Indigenous peoples and their traditional lands and waters (Clark 2002; Hooks and Smith 2004; Harris and Harper 2011) (Boone and Buckley 2017; S. Harris and Harper 2011; Hooks and Smith 2004; Vickery and Hunter 2016; Wakild 2013). Such historical perspectives, as we demonstrate through the next examples of wetland drainage, flooding and water pollution, offer essential insights into how environmental injustices accumulated over time and that historical injustices are in fact at the heart of the present-day environmental justice issues facing iwi in Aotearoa. Moreover, some scholars argue that without an appreciation of histories, contemporary issues (be it freshwater degradation, climate change, biodiversity, poverty, discriminatory policies) are open to misinterpretation. As Lord and Shutkin wrote in 1994: “To approach history casually and complacently is to evade history's inevitably multiplications facts and to mask the many meanings the facts could support" (Lord and Shutkin 1994, 5) (Lord and Shutkin 1994, p. 5). The deliberate or incidental disregard of histories presents significant implications for not only how people perceive Māori or Aotearoa New Zealand histories but also their understandings of environmental justice (Lord and Shutkin 1994).

In the specific context of Indigenous environmental justice, an everexpanding body of Indigenous and decolonial scholarship demonstrates the interwoven relationships between colonialism and environmental injustice (Curley 2019; Dhillon 2020; McGregor 2014; Whyte 2018; Winter 2019). In the next three chapters, we highlight how settler colonialism is not confined to the past and continues to be acted on and evolve; it is thus, critical to consider settler colonialism as an ongoing process that continues to shape Aotearoa New Zealand in the twentieth century. In the next chapter (Chap. 4) we provide an in-depth exploration of settler-led efforts to remove the wetlands of the Waipā River, and how those ecologically transformative acts resulted in a litany of environmental injustices for generations of Maori who whakapapa to the waterscapes of Te Awa o Waipā. 


\section{References}

Adams, P. (2013). Fatal Necessity: British Intervention in New Zealand, 1830-1847. Wellington: Bridget Williams Books.

Anderson, A. (2002). A Fragile Plenty: Pre-European Maori and the New Zealand Environment. In E. Pawson \& T. Brooking (Eds.), Environmental Histories of New Zealand (pp. 19-34). Auckland: Oxford University Press.

Anderson, A. (2003). Prodigious Birds: Moas and Moa-Hunting in New Zealand. Cambridge: Cambridge University Press.

Anderson, A. (2016). The Making of the Maori Middle Ages. Journal of New Zealand Studies, 23, 2.

Anderson, A., Binney, J., \& Harris, A. (2012). Tangata Whenua: An Illustrated History. Wellington: Bridget Williams Books.

Anderson, A., Binney, J., \& Harris, A. (2014). Tangata Whenua: An Illustrated History. Wellington: Bridget Williams Books.

Anderson, A., Binney, J., \& Harris, A. (2015). Tangata Whenua: A History. Wellington: Bridget Williams Books.

Ataria, J., Mark-Shadbolt, M., Mead, A. T. P., Prime, K., Doherty, J., Waiwai, J., et al. (2018). Whakamanahia Te mātauranga o te Māori: Empowering Māori Knowledge to Support Aotearoa's Aquatic Biological Heritage. New Zealand Journal of Marine and Freshwater Research, 52(4), 467-486.

Attwood, B. (2001). Learning about the Truth: The Stolen Generations Narrative. Telling Stories: Indigenous History and Memory in Australia and New Zealand, 183-212.

Attwood, B. (2014). Law, History and Power: The British Treatment of Aboriginal Rights in Land in New South Wales. The Journal of Imperial and Commonwealth History, 42(1), 171-192.

Ballantyne, T. (2012). Webs of Empire: Locating New Zealand's Colonial Past. Wellington: Bridget Williams Books. Retrieved April 21, 2017, from https:// books.google.co.nz/books?hl=en\&lr=\&id=o7ipY4SmDqoC\&oi=fnd\&pg= PR2\&dq=related:rMTvJd8z9nQJ:scholar.google.com/\&ots=9MSbl8yiyI\&s ig=vt6yqzedN4BM9d9ozDdAX8pKrz8.

Ballara, A. (1998). Iwi: The Dynamics of Māori Tribal Organisation from C.1769 to C.1945. Wellington: Victoria University Press.

Bambridge, T. (2013). The Rahui: Legal Pluralism, Environment, and Land and Marine Tenure in Polynesia. Canberra: ANUE Press. 
Ban, C. (1998). Wetland Archaeological Sites in Aotearoa (New Zealand) Prehistory. Hidden Dimensions: The Cultural Significance of Wetland Archaeology, 1, 47.

Barber, L. (1978). The View from Pirongia: The History of Waipa County. Te Awamutu: Richards Publishing in association with Waipa County Council.

Barrett, G. (2012). Wai 898 A109 Oral and Traditional History Volume Ngāti Tamainupō, Kōtara and Te Huaki (Waitangi Tribunal). Wellington: Crown Forestry Rental Trust. Retrieved May 26, 2020, from https://forms.justice. govt.nz/search/Documents/WT/wt_DOC_42325213/Wai\%20 898\%2C\%20A109.pdf.

Bassett, K. N., Gordon, H. W., Nobes, D. C., \& Jacomb, C. (2004). Gardening at the Edge: Documenting the Limits of Tropical Polynesian Kumara Horticulture in Southern New Zealand. Geoarchaeology, 19(3), 185-218.

Belgrave, M. (2017). Dancing with the King: The Rise and Fall of the King Country, 1864-1885. Auckland University Press.

Belgrave, M., Belgrave, D., Proctor, J., Joy, M., Togher, S., Young, G., et al. (2011). Te Rohe Pōtae Environmental and Wāhi Tahu Report (A Report Commissioned by the Crown Forestry Rental Trust for the Waitangi Tribunal's Te Rohe Pōtae District Inquiry No. A/76). Wellington: Crown Forestry Rental Trust.

Belich, J. (1996). Making Peoples: A History of the New Zealanders, from Polynesian Settlement to the End of the Nineteenth Century. Auckland: Penguin Press.

Belich, J. (2009). Replenishing the Earth: The Settler Revolution and the Rise of the Angloworld. Oxford: Oxford University Press.

Belich, J. (2015). The New Zealand Wars and the Victorian Interpretation of Racial Conflict. Auckland: Auckland University Press.

Best, E. (1904). Notes on the Custom of Rahui. Its Application and Manipulation, as Also Its Supposed Powers, Its Rites, Invocations and Superstitions. The Journal of the Polynesian Society, 13 2(50), 83-88.

Best, E. (1930). Maori Agriculture. Cultivated Food-Plants of the Maori and Native Methods of Agriculture. The Journal of the Polynesian Society, 39 4(156), 346-380.

Best, E. (1931). Maori Agriculture. Cultivated Food-Plants of the Maori and Native Methods of Agriculture. (Continued). The Journal of the Polynesian Society, 40 1(157), 1-22.

Binney, J. (2001). The Native Land Court and the Maori Communities. In J. Binney, J. Bassett, \& E. Olssen (Eds.), The Shaping of History: Essays from 
the New Zealand Journal of History (p. 143). Wellington: Bridget Williams Books.

Boast, R. (2008). Buying the Land, Selling the Land: Governments and Mãori Land in the North Island 1865-1921. Wellington: Victoria University Press. Boast, R. P. (2017). The Native Land Court and the Writing of New Zealand History. Law \& History, 4, 145.

Boone, C. G., \& Buckley, G. L. (2017). Historical Approaches to Environmental Justice. In R. Holifield, J. Chakraborty, \& G. Walker (Eds.), The Routledge Handbook of Environmental Justice (pp. 222-230). New York and London: Taylor \& Francis.

Borell, M., \& Joseph, R. (2012). Ngāti Ti Apakura Te Iwi Ngāti Apakura Mana Motuake. Report for Ngäti Apakura Claimants and the Waitangi Tribunal. Wai 898 A/097. Prepared for the Ngäti Apakura claimants for Te Rohe Pōtae Inquiry (Wai 898) and Commissioned by the Crown Forestry Rental Trust (No. Wai 898 A/097). Wellington: Crown Forestry Rental Trust.

Boswijk, G., \& Johns, D. (2018). Assessing the Potential to Calendar Date Māori Waka (Canoes) Using Dendrochronology. Journal of Archaeological Science: Reports, 17, 442-448.

Boulton, L. (2007). Hapu and Iwi Land Transactions with the Crown and Europeans in Te Rohe Potae Inquiry District, c.1840-1865 (Waitangi Tribunal No. A70). Wellington: Waitangi Tribunal.

Brookes, B. (2016). A History of New Zealand Women. Wellington: Bridget Williams Books.

Buck, P. (1950). The Coming of the Mãori. Wellington: Whitcombe \& Tombs. Cassels, R. (1972a). Locational Analysis of Prehistoric Settlement in New Zealand. The Australian Journal of Anthropology, 8(3), 212.

Cassels, R. (1972b). Human Ecology in the Prehistoric Waikato. The Journal of the Polynesian Society, 81(2), 196-247.

Chan, K., \& Fan, C. (2018). The Principle of Contra Proferentem and the Interpretation of Arbitration Agreements (SSRN Scholarly Paper No. ID 3357912). Rochester, NY: Social Science Research Network.

Collins, A., Turner, K., \& Te Huia, M. K.-H. (2012). Wai 898 A94 Te Kurutao a Maahanga Te Pù o te Tao Te Pü Kotahitanga Oral and Traditional History Volume of Ngāti Maahanga (Waitangi Tribunal). Wellington: Crown Forestry Rental Trust. Retrieved April 25, 2020, from https://forms.justice.govt.nz/ search/Documents/WT/wt_DOC_42292535/Wai\%20898\%2C\%20 A094.pdf. 
Cowan, J. (1901). The Romance of the Rohepotae. New Zealand Illustrated Magazine, $I V, 32$.

Cromarty, P., \& Scott, D. A. (1995). A Directory of Wetlands in New Zealand. Wellington: Department of Conservation.

Cummins, P., Ward, C., \& Museum, K. (2004). A History of Kawhia \& Its District. Kawhia, NZ: Kawhia Museum.

Cunningham, M. (2014). The Environmental Management of the Waipa River and Its Tributaries. Case-Study Commissioned by the Waitangi Tribunal for Te Rohe Potae district inquiry (Wai 898) (District Inquiry Research Report No. A150 (Wai 868_). Wellington: Waitangi Tribunal.

Curley, A. (2019). "Our Winters' Rights": Challenging Colonial Water Laws. Global Environmental Politics, 19(3), 57-76.

Davidson, J., Findlater, A., Fyfe, R., MacDonald, J., \& Marshall, B. (Eds.). (2011). Connections with Hawaiki: The Evidence of a Shell Tool from Wairau Bar, Marlborough, New Zealand. Research Report, 2(2), 10.

Dhillon, C. M. (2020). Indigenous Feminisms: Disturbing Colonialism in Environmental Science Partnerships. Sociology of Race and Ethnicity, 2332649220908608. https://doi.org/10.1177/2332649220908608.

Downes, T. W. (1918). Notes on Eels and Eel-weirs (Tuna and Pa-tuna). Transactions and Proceedings of the New Zealand Institute, 50, 296-316.

Durie, E. T. (1994). Custom Law: Address to the New Zealand Society for Legal and Social Philosophy. Victoria University of Wellington Law Review, 24, 325.

Ellison, S., Greenshill, A., Hamilton, M., Te Kanawa, M., \& Rickard, J. (2012). Wai 898 A99 Tainui Oral and Traditional Historical Report (Waitangi Tribunal). Wellington: Crown Forestry Rental Trust. Retrieved May 1, 2020, from https://forms.justice.govt.nz/search/Documents/WT/wt_DOC_4231 7979/Wai\%20898\%2C\%20A099.pdf.

Firth, R. (2012). Primitive Economics of the New Zealand Maori (Routledge Revivals). London: Routledge.

Forster, M. E. (2012). Hei Whenua Papatipu: Kaitiakitanga and the Politics of Enhancing the Mauri of Wetlands (Thesis). Massey University. Retrieved May 4, 2020, from https://mro.massey.ac.nz/bitstream/handle/10179/3336/02_ whole.pdf.

Francis, A. (2011). The Rohe Potae Commerical Economy in the Mid-Nineteenth Centuryl, c. 1830-1886 (Report commissioned by the Waitangi Tribunal for Te Rohe Potae District Inquiry (Wai 898) No. Wai 898 A/26). Wellington: Waitangi Tribunal. 
Furey, L. (n.d.). Maori Gardening: An Archaeological Perspective. Wellington: Science \& Technical Publishing Department of Conservation.

Grammond, S. (1994). Aboriginal Treaties and Canadian Law. Queen's Law Journal, 20, 57.

Grimshaw, P. (2002). Interracial Marriages and Colonial Regimes in Victoria and Aotearoa/New Zealand. Frontiers: A Journal of Women Studies, 23(3), 12-28.

Gumbley, W., Higham, T. F. G., \& Low, D. J. (2004). Prehistoric Horticultural Adaptation of Soils in the Middle Waikato Basin: Review and Evidence from S14/201 and S14/185, Hamilton. New Zealand Journal of Archaeology, 25(2003), 5-30.

Haar, J. (2009). Entrepreneurship and Maori Cultural Values: Using 'Whanaungatanga' to Understanding Maori Business. NZJABR, 7(1), 16.

Hammer, G. E. J. (1991). A Pioneer Missionary: Raglan to Mokau 1844-1880: Cort Henry Schnackenberg. Wesley Historical Society (New Zealand): Auckland.

Hargreaves, R. P. (1959). The Maori Agriculture of the Auckland Province in the Mid-Nineteenth Century. The Journal of the Polynesian Society, 68(2), 61-79. Harmsworth, G., Awatere, S., \& Robb, M. (2016). Indigenous Māori Values and Perspectives to inform Freshwater Management in Aotearoa-New Zealand. Ecology and Society, 21(4).

Harris, S., \& Harper, B. (2011). A Method for Tribal Environmental Justice Analysis. Environmental Justice, 4(4), 231-237.

Healy, S., Huygens, I., \& Murphy, T. (2012). Ngapuhi Speaks: He Whakaputanga and Te Tiriti o Waitangi: Independent Report on Ngapubi Nui Tonu Claim. Te Kawariki \& Network Waitangi Whangarei.

Hikuroa, D. (2016). Mātauranga Māori-The ūkaipō of Knowledge in New Zealand. Journal of the Royal Society of New Zealand.

Hogg, A., Gumbley, W., Boswijk, G., Petchey, F., Southon, J., Anderson, A., et al. (2017). The First Accurate and Precise Calendar Dating of New Zealand Māori Pā, using Otāhau Pā as a Case Study. Journal of Archaeological Science: Reports, 12, 124-133.

Hooks, G., \& Smith, C. L. (2004). The Treadmill of Destruction: National Sacrifice Areas and Native Americans. American Sociological Review, 69(4), 558-575.

Horrocks, M., Smith, I. W., Nichol, S. L., \& Wallace, R. (2008). Sediment, Soil and Plant Microfossil Analysis of Maori Gardens at Anaura Bay, Eastern North Island, New Zealand: Comparison with Descriptions made in 1769 
by Captain Cook's Expedition. Journal of Archaeological Science, 35(9), 2446-2464.

Internal Affairs. (Undated). Internal Affairs Department of Wildlife Service, "Lake Ngaroto: Inventory and Management Plan", Draft, Undated, AANS W3832 18, 30/1/21, Archives New Zealand, Wellington. Unpublished.

Irwin, G. (2013). Wetland Archaeology and the Study of Late Māori Settlement Patterns and Social Organisation in Northern New Zealand. The Journal of the Polynesian Society, 4(122), 311-332.

Jackson, M. (1993). Land Loss and the Treaty of Waitangi. Te Ao Märama: Regaining Aotearoa. Mäori Writers Speak Out, 2.

Jones, C. (2016). New Treaty, New Tradition: Reconciling New Zealand and Maori Law. Toronto: University of British Columbia. Retrieved June 12, 2019, from https://books.google.co.nz/books?hl=en\&lr=\&id=DSLCDAAAQBAJ $\& o \mathrm{i}=$ fnd $\& \mathrm{pg}=\mathrm{PT} 5 \& \mathrm{dq}=\mathrm{Jones}+2016+\mathrm{New}+$ Treaty \&ots $=09 \mathrm{dWY}$ fMZ0\&sig=vEDmsW4b2_KETAJpQfJWLcrDjRg\#v=onepage \&q=Jo nes $\% 202016 \% 20 \mathrm{New} \% 20$ Treaty\&f=false.

Kennedy, N. C. K. (2017). Kaitiakitanga o te Taiao-Reconciling Legislative Provisions and Outcomes for Mãori (Thesis). University of Waikato. Retrieved May 4, 2019, from https://researchcommons.waikato.ac.nz/handle/10 $289 / 11121$.

Leach, H. (2005). Gardens without Weeds? Pre-European Maori Gardens and Inadvertent Introductions. New Zealand Journal of Botany, 43(1), 271-284.

Lord, C. P., \& Shutkin, W. A. (1994). Environmental Justice and the Use of History. Boston College Environmental Affairs Law Review, 22(1), 1-26.

Lorrey, A. M., Boswijk, G., Hogg, A., Palmer, J. G., Turney, C. S. M., Fowler, A. M., et al. (2018). The Scientific Value and Potential of New Zealand Swamp Kauri. Quaternary Science Reviews, 183, 124-139.

Luiten, J. (2011). Local Government in Te Rohe Potae (A Report Commissioned by the Waitangi Tribunal for the Te Rohe Potae Casebook Research Program). Wellington: Waitangi Tribunal.

Marsden, M. (2003). The Woven Universe: Selected Writings of Rev. Mãori Marsden. Otaki: Estate of Rev. Māori Marsden.

Matthews, P. (1985). Nga taro o Aotearoa. The Journal of the Polynesian Society, 94(3), 253-272.

McGregor, D. (2014). Traditional Knowledge and Water Governance: The Ethic of Responsibility. AlterNative: An International Journal of Indigenous Peoples, 10(5), 493-507.

Mead, H. M. (2016). Tikanga Maori (Revised Edition): Living by Maori Values. Wellington: Huia Publishers. 
New Zealand Government. (1865). Proclamation of Native Lands Under the New Zealand Settlements Act. Daily Southern Cross, p. 5.

Ngata, S. A. T. (2004). Ngā Möteatea. Auckland: Auckland University Press.

Lord Normanby. (1908). Lord Normanby to Captain Hobson, R.N. Downing

Street, 15 August 1838. In R. McNab (Ed.), Historical Records of New Zealand, Vol. I. Wellington: John Mackey. Retrieved March 19, 2020, from http://nzetc.victoria.ac.nz/tm/scholarly/tei-McN01Hist-t1-b10-d135.html.

O'Malley, V. (2013). The Meeting Place: Maori and Pakeha Encounters, 1642-1840. Auckland: Auckland University Press.

O'Malley, V. (2016). The Great War for New Zealand: Waikato 1800-2000. Wellington: Bridget Williams Books.

O'Malley, V. (2017). He Whakaputanga: The Declaration of Independence, 1835.

Wellington: Bridget Williams Books.

Orange, C. (2015). The Treaty of Waitangi. Wellington: Bridget Williams Books. Parsons, M., \& Fisher, K. (2020). Indigenous Peoples and Transformations in Freshwater Governance and Management. Current Opinion in Environmental Sustainability. https://doi.org/10.1016/j.cosust.2020.03.006.

Parsons, M., \& Nalau, J. (2016). Historical Analogies as Tools in Understanding Transformation. Global Environmental Change, 38, 82-96.

Parsons, M., Nalau, J., Fisher, K., \& Brown, C. (2019). Disrupting Path Dependency: Making Room for Indigenous Knowledge in River Management. Global Environmental Change, 56, 95-113.

Parsonson, A. (2017). The Fate of Maori Land Rights in Early Colonial New Zealand: The Limits of the Treaty of Waitangi and the Doctrine of Aboriginal Title. Law, History, Colonialism. Manchester University Press. Retrieved March 19, 2020, from https://www.manchesterhive.com/view/97815261 19704/9781526119704.00021.xml.

Paterson, L. (2010). Hawhekaihe: Maori Voices on the Position of "Half-castes"

Within Maori Society. The Journal of New Zealand Studies, 9. https://doi. org/10.26686/jnzs.v0i9.121.

Pauling, C., \& Ataria, J. (2010). Tiaki Para: A Study of Ngäi Tahu Values and Issues Regarding Waste. Lincoln: Manaaki Whenua Press.

Petrie, H. (2013). Chiefs of Industry: Maori Tribal Enterprise in Early Colonial New Zealand. Auckland: Auckland University Press.

Pick, R. D. (1967). An Island Occupation Site on Lake Ngaroto on Pierce's Farm at the Northern End of the Lake. The Journal of the Te Awamutu Historical Society, 2(1), 19-21. 
Pick, R. D. (1968). Waikato Swamp and Island Pa. New Zealand Archaeological Association Newsletter, 11(1), 30-35.

Pond, W. (1997). The Land with All Woods and Water, Rangahaua Whanui National Theme $U$ (p. 123). Wellington: Legislation Direct.

Pool, I. (2015). Maori Demography and the Economy to 1840. In Colonization and Development in New Zealand between 1769 and 1900 (pp. 151-176). Springer.

Robb, M. J. G. (2014). When Two Worlds Collide: Mātauranga Mãori, Science and Health of the Toreparu Wetland (Thesis). University of Waikato. Retrieved May 4, 2019, from https://researchcommons.waikato.ac.nz/handle/10 $289 / 8776$.

Salmond, A. (2017). Tears of Rangi: Experiments Across Worlds. Auckland: Auckland University Press.

Salmond, A. (2018). Two Worlds: First Meetings Between Maori and Europeans 1642-1772. Auckland: Penguin Group New Zealand, Limited.

Schnackenberg, E. H. (1935). The Pohutukawas of Kawhia: Tales, Traditions \& Legends Relating to Kawhia's Famous Christmas Trees. Kawhia: Kawhia Settler.

Shawcross, K. (1967). Fern-Root, and the Total Scheme of 18th Century Maori Food Production in Agricultural Areas. The Journal of the Polynesian Society, 76(3), 330-352.

Shawcross, W. (1968). The Ngaroto Site. New Zealand Archaeological Association Newsletter, 11(1), 2-29.

Smith, S. P. (2011). Hawaiki: The Original Home of the Maori: With a Sketch of Polynesian History. Christchurch: Cambridge University Press.

Stevens, K., \& Wanhalla, A. (2017). Intimate Relations: Kinship and the Economics of Shore Whaling in Southern New Zealand, 1820-1860. The Journal of Pacific History, 52(2), 135-155.

Stirling, B. (2016). From Busby to Bledisloe: A History of the Waitangi Lands. A Report Commissioned by the Waitangi Marae Trustees and the James Henare Maori Research Centre (Waitangi Tribunal No. Wai 1040 W5). Unpublished: Waitangi Marae Trustess and the James Henare Maori Research Centre.

Stokes, E. (1988). Mokau: Mãori Cultural and Historical Perspectives. Hamilton: University of Waikato.

Stokes, E. (2013). Contesting Resources: Māori, Pākehā and a Tenurial Revolution. In E. Pawson, \& T. Brooking (Eds.), Making a New Land: Environmental Histories of New Zealand (pp. 52-69). University of Otago Press: Dunedin. 
Suter, B. (2014). The Contra Proferentem Rule in the Reports of the Waitangi Tribunal. Retrieved March 19, 2020, from http://researcharchive.vuw.ac.nz/ handle/10063/4404.

Tāne, W. (2017). Cultural Impact Assessment: An Assessment of Cultural Impacts of the Proposed Happy Valley Milk Ltd Dairy Factory on Redlands Road, Otorohanga, July 2017. Report commissioned by Nehenehenui Regional Management Committee. Ōtorohanga: Nehenehenui Regional Management Committee.

Taumoefolau, M. (1996). FROM * SAU 'ARIKI TO HAWAIKI. The Journal of the Polynesian Society, 105(4), 385-410.

Tauriki, M., Ngaia, T. I., Roa, T., Maniapoto-Anderson, R., Barrett, A., Douglas, T., et al. (2012). Ngāti Maniapoto Mana Motuhake Report for Ngäti Maniapoto Claimants and the Waitangi Tribunal. A/110 (Waitangi Tribunal No. Wai 898 A/110). Hamilton: Crown Forestry Rental Trust.

Tawhai, V., \& Gray-Sharp, K. (2011). Always Speaking: The Treaty of Waitangi and Public Policy. Wellington: Huia Publishers.

Te Hurinui Jones, P. (1995). Nga iwi o Tainui: The Traditional History of the Tainui People: ngà koorero tuku iho a ngā tüpuna. Auckland: Auckland University Press.

Thorne, F. (2011). Te Maru-o-Hikairo: Oral and Traditional History Report of Ngati Hikairo (Wai 898 A98). Wellington: Waitangi Tribunal.

Unknown Author. (1864). The Native Rebellion. New Zealand Herald, 25 June, p. 5. Auckland.

Unknown Author. (1902). Art. Ii.-The Cultivation and Treatment of the Kumara by the Primitive Maoris. Transactions and Proceedings of the Royal Society of New Zealand, 42.

Vickery, J., \& Hunter, L. M. (2016). Native Americans: Where In Environmental Justice Research? Society \& Natural Resources, 29(1), 36-52.

Waitangi Tribunal. (1993). The Waitangi Tribunal and the Motunui-Waitara Claim. Wellington: Waitangi Tribunal.

Waitangi Tribunal. (2014). He Whakaputanga me te Tiriti the Declaration and the Treaty: The Report on Stage 1 of the Te Paparahi o Te Raki Inquiry. Wellington: Legislation Direct.

Waitangi Tribunal. (2018). Te Mana Whatu Ahuru: Report on Te Rohe Pōtae Claims Pre-Publication Version Parts I and II. Wellington: Unpublished.

Wakild, E. (2013). Environmental Justice, Environmentalism, and Environmental History in Twentieth-Century Latin America. History Compass, 11(2), 163-176. https://doi.org/10.1111/hic3.12027. 
Wanhalla, A. (2015). In/visible Sight: The Mixed-Descent Families of Southern New Zealand. Wellington: Bridget Williams Books.

Wanhalla, A. (2017). Intimate Connections: Governing Cross-Cultural Intimacy on New Zealand's Colonial Frontier. Law \& History, 4, 45.

Whyte, K. (2018). Settler Colonialism, Ecology, and Environmental Injustice. Environment and Society, 9(1), 125-144. https://doi.org/10.3167/ares. 2018.090109.

Williams, D. V. (1999). "Te Kooti Tango Whenua": The Native Land Court 1864-1909. Wellington: Huia Publishers.

Winter, C. J. (2019). Does Time Colonise Intergenerational Environmental Justice Theory? Environmental Politics, 1-19. https://doi.org/10.108 0/09644016.2019.1569745.

Worthy, T. H., \& Swabey, S. E. J. (2002). Avifaunal Changes Revealed in Quaternary Deposits Near Waitomo Caves, North Island, New Zealand. Journal of the Royal Society of New Zealand, 32(2), 293-325.

Open Access This chapter is licensed under the terms of the Creative Commons Attribution 4.0 International License (http://creativecommons.org/licenses/ by/4.0/), which permits use, sharing, adaptation, distribution and reproduction in any medium or format, as long as you give appropriate credit to the original author(s) and the source, provide a link to the Creative Commons licence and indicate if changes were made.

The images or other third party material in this chapter are included in the chapter's Creative Commons licence, unless indicated otherwise in a credit line to the material. If material is not included in the chapter's Creative Commons licence and your intended use is not permitted by statutory regulation or exceeds the permitted use, you will need to obtain permission directly from the copyright holder.

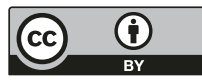

